\title{
Westinghouse Hanford Company FY 1995 Materials Management Plan (MMP)
}

M. C. Higginson

Date Published

October 1994

Prepared for the U.S. Department of Energy Office of Environmental Restoration and Waste Management

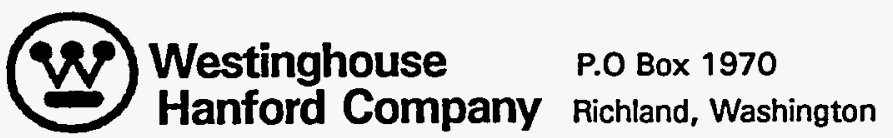

Hanford Operations and Engineering Contractor for the

U.S. Department of Energy under Contract DE-AC06-87RL10930 


\section{DISCLAIMER}

This report was prepared as an account of work sponsored by an agency of the United States Government. Neither the United States Government nor any agency thereof, nor any of their employees, make any warranty, express or implied, or assumes any legal liability or responsibility for the accuracy, completeness, or usefulness of any information, apparatus, product, or process disclosed, or represents that its use would not infringe privately owned rights. Reference herein to any specific commercial product, process, or service by trade name, trademark, manufacturer, or otherwise does not necessarily constitute or imply its endorsement, recommendation, or favoring by the United States Government or any agency thereof. The views and opinions of authors expressed herein do not necessarily state or reflect those of the United States Government or any agency thereof. 


\section{DISCLAIMER}

Portions of this document may be illegible in electronic image products. Images are produced from the best available original document. 


\section{RELEASE AUTHORIZATION}

Document Number: WHC-SP-1139

Document Title: Westinghouse Hanford Company FY 1995 Materials Management Plan (MMP).

Release Date: $\quad 10 / 11 / 94$

This document was reviewed following the procedures described in WHC-CM-3-4 and is:

APPROVED FOR PUBLIC RELEASE

****************

WHC Information Release Administration Specialist:

Christine Mrillengham

CHRISTINE WILLINGHAM

$10 / 11 / 94$

(Signature)

(Date) 


\section{WHC FY 1995 Materials Management Plan (MMP)}

\section{Table of Contents}

Hanford Plant Priorities $\ldots \ldots \ldots \ldots$

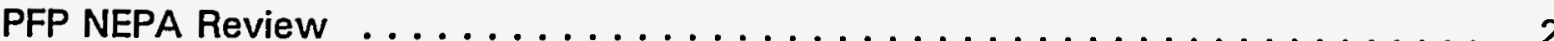

Hanford Site Irradiated Fuel Els $\ldots \ldots \ldots \ldots \ldots \ldots \ldots$

Material Management Plan Assumptions and Issues $\ldots \ldots \ldots \ldots \ldots \ldots$

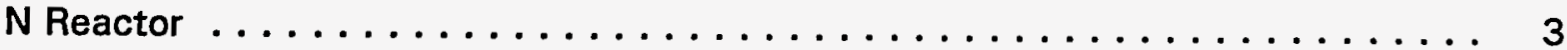

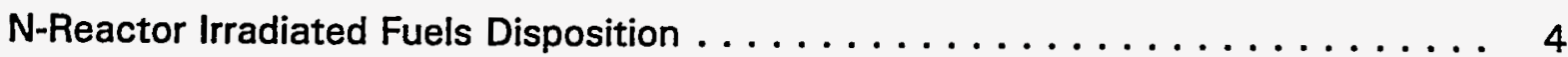

300 Area Fuel Fabrication Facilities $\ldots \ldots \ldots \ldots \ldots \ldots \ldots \ldots \ldots \ldots \ldots \ldots \ldots$

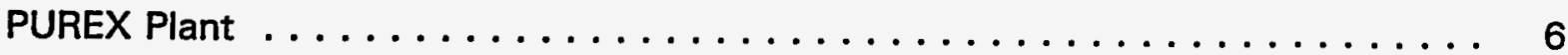

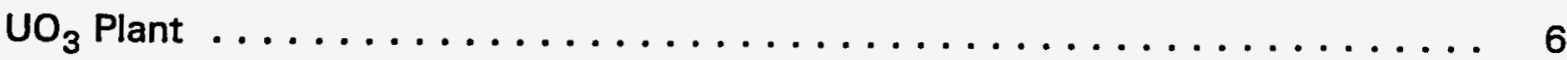

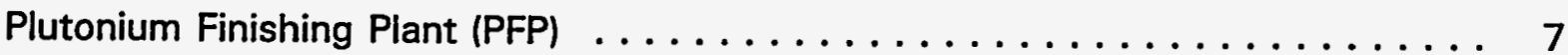

Plutonium Stored in PFP Vaults $\ldots \ldots \ldots \ldots \ldots \ldots$

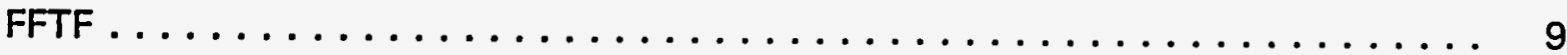

Summary Assumptions $\ldots \ldots \ldots \ldots \ldots \ldots \ldots \ldots \ldots \ldots \ldots \ldots \ldots$

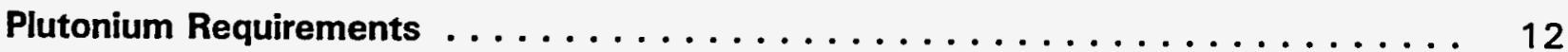

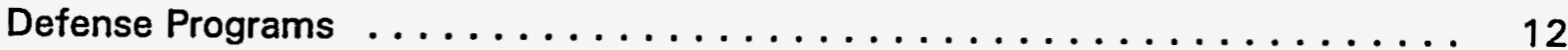

$<7 \%$ Pu-240 Product Shipments . . . . . . . . . . . . . . . 12

Fuel Grade Product Shipments . . . . . . . . . . . . . . . . . 12

Research \& Development Programs $\ldots \ldots \ldots \ldots \ldots \ldots \ldots \ldots \ldots \ldots$

FFTF Driver Fuel and LMFBR Test Fuel . . . . . . . . . . . . . . . . 12

Certified Ceramic Grade Plutonium Oxide Inventory . . . . . . . . . . . 12

Restricted Use Plutonium Allocations . . . . . . . . . . . . . . 13

Summary Tables (See list on page iv) $\ldots \ldots \ldots \ldots \ldots \ldots \ldots$

Explanatory Notes for Plutonium Utilization Tables . . . . . . . . . . . . . . . . 21

Table $9-<7 \%$ Pu-240 Grade Plutonium Utilization/Inventory Projection . . . . 22

Table 10 - FG Plutonium Utilization . . . . . . . . . . . . . . . 25

Table 11 - Power Reactor Grade (PRG) Plutonium Utilization . . . . . . . . . . . 31

Appendix A - Uranium Usage Tables . . . . . . . . . . . . . 36

Appendix B - Other Special Nuclear Materials . . . . . . . . . . . . . 41 


\section{List of Tables}

Table

Page

1A. $\quad$ N Reactor Irradiated Fuel In K Basins . . . . . . . . . . . . . . . . . . . 14

1B. Isotopics of Stored $\mathrm{N}$ Reactor Irradiated Fuels $\ldots \ldots \ldots \ldots \ldots \ldots$

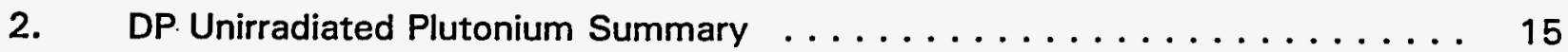

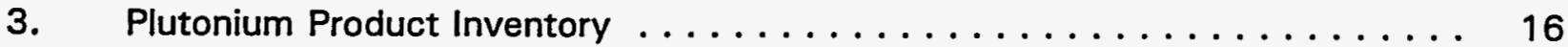

4. Unirradiated Plutonium Scrap Inventory $\ldots \ldots \ldots \ldots \ldots \ldots$

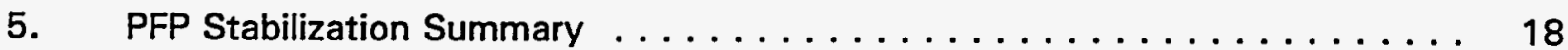

6. Forecast of Fuel-Grade and Power-Reactor-Grade Plutonium Unirradiated Returns .............................. 19

7. Forecast of Fuel-Grade and Power-Reactor-Grade Plutonium Withdrawals . . . 19

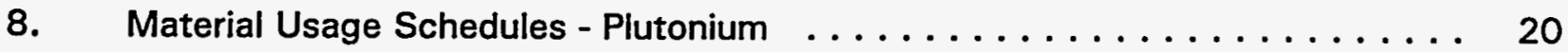

9. $<7 \%$ Pu-240 Grade Plutonium Utilization/Inventory Projection . . . . . . . 23

10. Fuel Grade Plutonium Utilization/Inventory Projection . . . . . . . . . . . . 26

11. Power Reactor Grade Plutonium Utilization/Inventory Projection . . . . . . . . . 32

12. RL Inventory Allocation of Restricted Use Plutonium . . . . . . . . . 33

13. RL Receipts of NFS Plutonium Nitrate $\ldots \ldots \ldots \ldots \ldots \ldots \ldots \ldots$

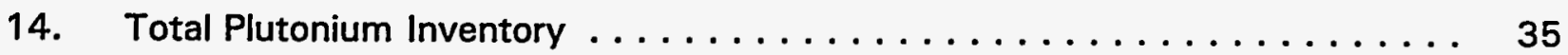

A-1. Fuel Fabrication Unirradiated Uranium Inventory (DP) . . . . . . . . . 37

A-2. DP/EM Enriched \& Normal Uranium Inventory and Usage . . . . . . . . 38

A-3. NE Unirradiated Uranium . . . . . . . . . . . . . . . . . . . . . . 39

A-4. NE Irradiated Uranium . . . . . . . . . . . . . . . . . . 40

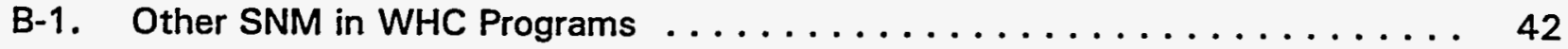




\section{WHC FY 1995 Materials Management Plan (MMP)}

\section{Hanford Plant Priorities}

The safe and sound operation of facilities and storage of nuclear material are top priorities within Hanford's environmental management, site restoration mission. The projected materials estimates, based on the Materials Management Plan (MMP) assumptions outlined below, were prepared for.Department of Energy (DOE) use in long-range planning. The Hanford MMP covers the period FY 1995 through FY 2005, as directed by DOE.

All DOE Richland Operations (RL) Office facilities are essentially funded by the Office of Transition and Facilities Management, Environmental Restoration and Waste Management (EM). These facilities include PUREX, the $\mathrm{UO}_{3}$ plant, N-Reactor, T-Plant, K-Basins, FFTF, PFP and the 300 Area Fuel Fabrication facilities. Currently DP provides partial funding for the latter two facilities. Beginning in FY 1996 (in accordance with DOE-HQ MMP assumptions), EM will fund expenses related to the storage, monitoring, and safeguarding of all Special Nuclear Material (SNM) in the PFP. Ownership and costs related to movement and/or stabilization of that material will belong to EM programs (excluding NE material). It is also assumed that IAEA will take over inventory validation and surveillance of EM owned SNM at this time (FY 1996).

The forecasted safe storage, stabilization and/or disposition of these nuclear materials is dependent upon receipt of the necessary direction and funding from DP, NE, and EM.

Nuclear material long term storage, processing and/or disposition plans presented in this document are dependent on two National Environmental Policy Act (NEPA) reviews, the PFP Environmental Impact Statement (EIS) and resulting Record of Decision (ROD) and the Hanford Site Irradiated Fuels EIS and ROD. With the exception of the planned stabilization of $22 \mathrm{~kg} \mathrm{Pu}$ at the PFP and the potential receipt of some fuel grade (FG) oxide from the Lawrence Livermore National Laboratory (LLNL), no other plutonium movements to or from Hanford are projected until these NEPA reviews are completed. This assumption may change in the future due to an Idaho court decision of June 28, 1993 which includes Hanford as a potential receiver site for spent nuclear fuel from naval, university, and foreign research reactors, and from other sites. 


\section{PFP NEPA Review}

An Environmental Impact Statement (EIS) currently being prepared to address stabilization and interim storage of plutonium bearing materials at the Plutonium Finishing Plant (PFP). A series of interim actions are being implemented to resolve those items which were considered to pose significant risks; these items will be remediated during EIS preparation. Ongoing, planned, and completed interim actions include downloading and disposition of solutions stored in the Plutonium Reclamation Facility (PRF); source term reduction of holdup material in the 232-Z building; duct remediation in 234-5; thermal stabilization and cementing plutonium bearing sludges; and development laboratory testing of corrosive plutonium solutions.

Current Status and Schedule: The EA for the PFP Stabilization Run was approved by DOE-RL in August 1994. The Notice of Intent (NOI) for the PFP EIS is completed in draft form and is currently undergoing formal review; publication is targeted for October 1994. The PFP EIS and Record of Decision (ROD) is not expected until CY 1996.

\section{Hanford Site Irradiated Fuel EIS}

A site EIS is planned to ensure that environmental factors are considered in decisions regarding the interim storage of irradiated fuel located in facilities at the Hanford Site. As currently planned, this EIS will also consider and identify technologies required to prepare the fuel for interim storage. The site EIS will satisfy site-specific NEPA review requirements for implementing the Record of Decision (ROD) resulting from the complexwide Spent Nuclear Fuel Programmatic EIS (SNF PEIS).

The inventory of irradiated fuels to be covered by the Hanford EIS includes approximately 2100 metric tons of $\mathrm{N}$ Reactor fuel, 16 metric tons of Shippingport Reactor (PWR Core II) fuel, 11 metric tons of FFTF fuel, 3 metric tons of single-pass reactor fuel and 2 metric tons of miscellaneous fuels.

\section{Current Status and Schedule:}

A draft Notice of Intent (NOI) to prepare the site EIS was submitted to DOE-HO in June, 1993. An earlier draft NOI had been transmitted to DOE-HO in January, 1992, but the activity had been placed on hold awaiting completion of the SNF PEIS and resolution of funding constraints. The current NOI will be revised to reflect recommendations in the SNF PEIS ROD. 
Currently, no funding is identified to begin preparation of the EIS in FY 1994. Fiscal Year 1995 funding has been provided to develop scoping studies that will identify reasonable alternatives to be considered in the EIS.

The NOI for the site EIS would be published in June 1995 when the SNF PEIS ROD is published. A tentative completion for the site EIS and ROD would be late FY 1996 or early FY 1997 provided funding is made available in FY 1995.

\section{Material Management Plan Assumptions and Issues}

The latest set of assumptions used in developing the RL MMP were provided by the DOE-Headquarters Office of Weapons and Materials Planning (DP-22) in a July 13, 1994 teletype to RL, Subject: Assumptions for FY 1995 Materials Management Plan (MMP). Assumptions for only one case were defined and no alternate cases were requested. DOE-RL has, however, amended these assumptions and included additional assumptions of their own in RL's letter to the President, WHC; MMP for the period FY 1995 through FY 2005, dated August 4, 1994. A summary of these assumptions appears on page 11 of this document.

\section{N Reactor}

In accordance with a cease-preservation directive received from DOE on September 23, 1991, N Reactor formally began the transition from cold standby to shutdown in FY 1992. An N Reactor Shutdown program plan (Rev. 2) was submitted to DOE in September 1991 with revision 4, implementing DOE Comments, being released in December 1993. The work described in this plan is scheduled for completion in September 1997 when N Reactor turnover to the Hanford Surplus Facilities Program for Decommissioning is achieved.

Significant progress this past year (as summarized below) occurred in the three areas: regulatory permitting, building demolition, and planning activities for deactivation.

Regulatory permitting accomplishments include approval of the Radiation Protection-Air Emissions Notice of Construction for $105 \mathrm{~N}$ Basin Stabilization by the Washington State Department of Health (WDOH), approval of the permit for National Emissions Standards 
for Hazardous Air Pollutants by the Environmental Protection Agency, and submittal of the Environmental Assessment (EA) for N Reactor Deactivation to DOE-RL.

Building demolition accomplishments include demolition of the $1100 \mathrm{~N}$ building, removal of the $1118 \mathrm{~N}$ and $1117 \mathrm{~N}$ trailers, and beginning the demolition process for $1101 \mathrm{~N}$.

Deactivation planning accomplishments include formation of the $100 \mathrm{~N}$ Pilot Project which placed all $100 \mathrm{~N}$ deactivation and restoration activities under one project, inclusion of the 100N Pilot Project within proposed Tri-Party Agreement (TPA) milestones, submittal of the $100 \mathrm{~N}$ Pilot Project Management Plan to the Tri-Party Agreement members, and revision and re-submittal of the Closure Plan to DOE.

\section{N-Reactor Irradiated Fuels Disposition}

Storage of N Reactor irradiated and miscellaneous spent fuel in water filled storage basins at Hanford will continue pending recommendations of the SNF PEIS and Hanford Site Irradiated Fuel EIS previously referenced. Material stored in K-East basin remains unencapsulated; material in $\mathrm{K}$-West basin is encapsulated.

A draft EA, Characterization of Stored Defense Production Special Nuclear Fuel and Associated Materials, was forwarded to DOE-RL for review on July 25, 1994. In addition a video survey of $\mathrm{K}$-East Basin canisters and fuel contents was completed, and work is planned to authorize, pull samples and/or characterize gas samples from encapsulated canisters, sludge samples from canisters in both $K$ basins, and irradiated fuel element samples from canisters in both $\mathrm{K}$ basins.

Construction to install seismic qualified isolation barriers between the basin storage area and discharge chute area has begun. Project completion is scheduled in early FY 1995 and will allow removal of radionuclides from water contained in the discharge chute area; water in this area will be maintained (kept free of any significant radionuclides contamination). This project is part of the resolution of an unreviewed safety question relating to the seismic performance of a construction joint in the basin.

DOE-RL, through outside consultants and contractors, is also preparing an engineering study to determine the feasibility of dry storage of irradiated fuels on the Hanford site. Dry storage would require a benign, essentially non-corrosive and stable condition suitable for an extended period (50 years or longer) of interim storage. Since there are various types of irradiated fuels and materials at Hanford, it will be necessary to address each of 
these on an individual basis. One plan being considered addresses the need for a Hanford 200 Area modular dry storage facility that can be expanded to accommodate the $\mathrm{N}$ Reactor irradiated fuel after it is prepared for dry storage.

K Basin clean-up proposals that employ the use of dry storage for $N$ Reactor irradiated fuels consider a demonstration program and implementation approach. Costs and schedules are being generated.

\section{Area Fuel Fabrication Facilities}

Shutdown and deactivation of the 300 Area Fuel Fabrication Facilities is assumed to occur by FY 2000 provided funding becomes available to relocate and store the unirradiated uranium inventory remaining from $\mathrm{N}$-Reactor fuel fabrication activities. Various options for consolidation and storage of this material were included in a WHC study completed in FY 1994; reference WHC-SD-CP-ES-163, Rev 0, Options Analysis for Uranium Consolidation, dated April 8, 1994. A recommendation for continued storage verses disposal could not be reached and is dependent on development of a national policy for the disposition of excess unirradiated depleted, normal, and low enriched uranium. Continued short term storage in the 300 Area (until a national policy is developed) is the preferred option provided costs are the primary drivers for DP and EM programs. If interim storage is required beyond FY 2000, the recommended alternative is to transfer, consolidate, and store this material in the $4732-\mathrm{C}$ warehouse in the Hanford 400 Area. In this case additional funding of 2.6 million dollars would be required (one time), but yearly operating expense requirements would decline by $\$ 190,000$ (from \$950K to \$760K).

Although, Hanford did ship 326 MTU of $0.95 \%$ U-235 enriched billets to the United Kingdom Ministry of Defense (UK MOD) in FY 1993 (authorized by the United States/United Kingdom Mutual Defense Agreement), the remaining inventory of normal and low enriched uranium billets will not ship to COGEMA Inc., the approved buyer of Hanford's excess uranium inventory, as previously planned. COGEMA made a decision not to extend their bid and therefore voided the sales transaction. Reasons cited were the time lag since the original bid, the change in availability of French processing facilities, and the changing world market for fuels that could be produced from this material. This uranium billet material will remain indefinitely (as discussed in the above paragraph) in the Hanford 300 Area along with unirradiated finished and unfinished fuel elements. 


\section{PUREX Plant}

In accordance with DOE-HO direction, the Plutonium Uranium Extraction Plant (PUREX) is currently being deactivated. The objective of deactivation is to place the PUREX facility in a passively safe, environmentally secure configuration, and ensure that this configuration is retained until decontamination and decommissioning (D\&D) take place. The PUREX/UO ${ }_{3}$ Deactivation Project Management Plan outlines the deactivation approach and the supporting technical, cost, and schedule baselines. Deactivation activities concentrate on removal, reduction, and stabilization of the radioactive and chemical materials remaining in the plant as well as the shutdown of utilities and effluents.

Currently, the majority of the PUREX chemical inventory has been redeployed to offsite users. Remaining actions are to neutralize approximately 19,814 liters of solution in tanks D5/E6 containing 9 kgs plutonium and 5.3 metric tons uranium (MTU) and to transfer this material to tank farms' double shell waste tanks by June of 1995 . In addition, details are being finalized to support the sale of 689,030 liters of the PUREX low specific activity nitric acid containing 7.3 MTU to British Nuclear Fuels, Ltd. in England (based on an unapproved change request). When the deactivation project is completed in September 1997 (based on change request), the PUREX facility will be unoccupied and locked pending eventual D\&D.

\section{$\mathrm{UO}_{3}$ Plant}

Phase II deactivation activities are currently underway at the Uranium Trioxide $\left(\mathrm{UO}_{3}\right)$ Plant. These activities consist of deactivating and/or decontaminating instruments and equipment, permanently shutting down and sealing off the utilities, and documenting existing conditions. Materials and equipment, as made available, are being redeployed to other facilities on the Hanford site. End state criteria was developed and is in the approval cycle. The $\mathrm{UO}_{3}$ deactivation project is scheduled for completion in May 1995 . However, at the current rate of progress, the project will be completed six months ahead of schedule in December 1994. Currently 662 metric tones of uranium oxide powder are stored at the $\mathrm{UO}_{3}$ Plant in T-hopper containers. This material was scheduled for shipment to COGEMA, however, due to cancellation of the sales transaction will remain at Hanford indefinitely. 


\section{Plutonium Finishing Plant (PFP)}

The PFP planned stabilization run previously reported in the FY 1993 and FY 1994 MMP documents has changed in the scope of material to be stabilized and in the method of stabilization to be used (see table 5 ).

The current stabilization plan schedules for treatment only plutonium bearing sludges (reactive scrap solids) stored in polyjars within the process gloveboxes in the PFP. These sludges contain $21 \mathrm{~kg}$ plutonium along with other chemical impurities; this amounts to $10 \%$ of the total plutonium contained in reactive materials at the PFP. The remaining $90 \%$ of reactive material plutonium is primarily contained in residual process solutions which are not now included in the stabilization plan. In addition the product plutonium nitrate solutions (containing $235 \mathrm{~kg} \mathrm{Pu}$ ) previously scheduled for stabilization are no longer included in the interim action stabilization plan.

Neither the Plutonium Reclamation Facility (PRF) nor the Remote Mechanical C (RMC) line will be used to complete the current stabilization plan. Instead, muffle furnaces will heat the chemically reactive sludges to approximately 500 to $1000^{\circ} \mathrm{C}\left(900\right.$ to $\left.1800^{\circ} \mathrm{F}\right)$. The resulting stable powder will be stored in PFP vaults as impure scrap oxide inventory.

It is estimated that the planned stabilization will require 400 to 600 batches of material resulting in approximately 150 containers (after packaging) for vault storage. There is sufficient storage capacity to accept this material.

An Environmental Assessment (EA), Sludge Stabilization at the PFP, was completed in June 1994 and submitted to DOE-RL for approval. Publishing of this document is expected in October 1994 (reference DOE-00978).

In addition to stabilizing the reactive scrap sludges outlined above, a small amount of high chloride solutions containing $1.3 \mathrm{~kg} \mathrm{Pu}$ are to be transloaded to the PFP Plutonium Process Support Laboratory for process testing. These tests are designed to demonstrate a process for converting this type solution to a stable, storable solid. Resulting data will provide input to the PFP EIS.

The reason for down-scoping the stabilization run stems from a DOE-RL and WHC management decision to require a PFP Environmental Impact Statement that expands the scope of review to include all alternatives for stabilization, clean out of the facility, and activities to support future environmental missions. Public involvement meetings held in 
the last half of CY 1993 prompted a DOE-RL decision not to restart PRF and RMC prior to obtaining a Record of Decision (ROD) on the EIS. At this time, it appears unlikely that the ROD will support either a PRF or RMC restart for stabilization.

\section{Plutonium Stored in PFP Vaults}

In order to reduce the number of project accounts containing plutonium inventory, some inventory realignment was initiated this past year; essentially all scrap material was consolidated into one: project (H-GE-0221-06S); standards and samples were also realigned into fewer accounts. Consolidation of material in holdup and in-process accounts along with further consolidation of the standards and samples material is planned in FY 1995. Other inventory reorganization proposals designed to improve efficiency of reporting and clarity and visibility of inventories and will also be assessed.

Fuel grade plutonium metal and oxide from the existing product inventory will continue to be supplied to the Office of Nuclear Energy (NE) projects as requested and as availability allows. The product inventory does, however, contain americium above product specification levels and may require some processing at another site before beneficial use.

It is assumed that EM programs will assume ownership of all plutonium at the PFP (excluding NE material) beginning in FY 1996. It is also assumed that in FY 1996, IAEA will take over inventory validation and surveillance of EM owned plutonium.

The May 24, 1994 Withdrawals and Returns Summary received from DOE-HQ in June 1994 schedules returns from LLNL only, and no withdrawals are projected for NE programs throughout the forecast period. Only material that meets Hanford acceptance criteria may be schedule for returns as storable SNM inventory at Hanford. Therefore, it is assumed that only $10 \mathrm{~kg} \mathrm{Pu}$ of the $51 \mathrm{~kg} \mathrm{Pu}$ scheduled will be received as stored inventory.

Interim storage of unirradiated plutonium extends through the reporting period of this document and will remain at the PFP. A Hanford unirradiated Plutonium disposition plan is dependent upon the previously addressed NEPA documentation (PFP EIS and ROD) due out in FY 1996.

In April 1994, DOE-HQ, Defense Programs (DP-22) directed operations offices to cancel the established Economic Discard Limit (EDL) methodology for unirradiated plutonium- 
bearing materials. DOE-RL directed WHC in August 1994 to develop a Plutonium Disposition Plan by October 94 that would serve as the technical basis for RL discard decisions. WHC management is organizing a team of experts to prepare a practical EDL methodology for Hanford plutonium and is assessing the cost of meeting this request. A WHC assessment of this request and a proposed plan of action will be prepared and forwarded to DOE-RL.

\section{FFTF}

In a December 15, 1993 memorandum, DOE-HQ directed its Richland Operations Office $(R L)$ to place the FFTF in a radiologically and industrially safe shutdown condition. The memorandum set a target date of 5 years to accomplish the shutdown. The reactor had previously been placed in a hot standby mode with the capability of restart.

The permanent shutdown directive is based on a decision made at DOE-HO that no combination of missions for the FFTF has a reasonable probability of financial viability over the next 10 years.

WHC management published an FFTF Shutdown Program Plan (WHC-SD-FF-SSP-004) on March 4, 1994. An aggressive Master FFTF Shutdown Schedule has been prepared, and WHC is actively working to complete program plan activities in accordance with this schedule. In addition, a revised EA (Shutdown of the FFTF, Hanford Site, Richland, WA) was submitted to DOE-RL on July 29,1994 for review.

Currently at the FFTF Reactor, all control rod drive mechanisms have been disabled, all fuel assemblies are being removed from the reactor vessel, appropriate systems have been placed in lay-up status.

Included in the steps necessary to complete FFTF shutdown requirements are the following primary activities:

- Defueling of the reactor vessel assemblies to existing sodium storage; replace with non-fuel components to ensure core configuration; wash irradiated fuel and transfer to above ground dry cask interim storage in the Hanford 400 Area pending final disposition.

- Wash 32 unirradiated assemblies (currently stored in sodium), load into shipping containers, and transfer to the PFP for interim storage. 
- Wash, load into shipping casks, and ship 7 sodium-bonded metal fuel assemblies plus sodium bonded metal and carbide pins to Idaho National Engineering Laboratory for storage.

- Transfer molten metallic sodium (after core defueling) to a new sodium facility yet to be constructed. In order to accommodate residuals, an inert gas atmosphere would be maintained to prevent any chemical reactions during long-term surveillance and maintenance.

- Convert stored sodium to a stable form at a future reaction facility still to be designed and constructed.

During the first four years of the transition to shutdown, approximately 90 percent of the plant systems are required to support hot sodium circulation. After that time period as systems become available for deactivation, the need for general maintenance and plant support will be reduced. Essentially all of the plant systems would be deactivated at final shutdown (January 2001) placing the FFTF in a long term monitoring phase. The total shutdown project completion date is scheduled for April 2002 on the FFTF Shutdown Master Schedule. No substantial increase in environmental impacts at Hanford are expected from the shutdown activities. 


\begin{tabular}{|c|c|}
\hline DOE-HQ Recommended Assumptions & DOE-RL Amended Assumptions and Comments \\
\hline Deactivate 300 Area Fuel Fabrication facilities by FY 2000 & Agree, provided funding available to relocate and store material. \\
\hline Deactivate and shutdown FFTF over a 5-7 year period & Agree \\
\hline Deactivate PUREX by FY 1997 & Agree \\
\hline Deactivate $\mathrm{UO}_{3}$ Plant by FY 2000 & WHC schedule is to deactivate by May 1995 (plant ready for D\&D at that time). \\
\hline $\begin{array}{l}\text { Begin encapsulation of } N \text {-Reactor irradiated fuel in } \\
\text { FY } 1995\end{array}$ & $\begin{array}{l}\text { Encapsulation pilot run to occur in FY 1995; pilot run will provide information to support } \\
\text { the containerization of irradiated fuel. }\end{array}$ \\
\hline MMP should reflect results of PFP EIS & $\begin{array}{l}\text { A Hanford unirradiated Pu disposition plan is dependent upon the PFP EIS and ROD } \\
\text { scheduled for completion in FY } 1996 \text {. Interim storage of unirradiaded Pu extends through } \\
\text { the reporting period of this document and will remain at the PFP. }\end{array}$ \\
\hline $\begin{array}{l}\text { Irradiated fuel disposition plans will be based on guidance } \\
\text { from the Office of Spent Nuclear Fuel Management, } \\
\text { Environmental Management (EM-37) }\end{array}$ & Agree \\
\hline $\begin{array}{l}\text { Other EM managed nuclear material disposition plans will } \\
\text { be based on guidance from the Northwestern Office, } \\
\text { Environmental Management (EM-65) }\end{array}$ & Agree \\
\hline $\begin{array}{l}\text { Hanford depleted, normal, and low enriched uranium will } \\
\text { be sold, bartered, andlor transferred to EM }\end{array}$ & $\begin{array}{l}\text { Defense Programs depleted, normal, and low enriched unirradiated uranium located at } \\
\text { Hanford is sold, bartered, or transferred to EM. }\end{array}$ \\
\hline $\begin{array}{l}\text { Beginning in FY } 1996 \text { EM will fund storage, monitoring } \\
\text { and safeguarding of all nuclear material in PFP }\end{array}$ & $\begin{array}{l}\text { Beginning in FY 1996, EM will fund expenses related to the storage, monitoring, and } \\
\text { safeguarding of all SNM in the PFP. Ownership, and costs related to movement and/or } \\
\text { stabilization of that material will belong to EM programs (excluding NE material). It is also } \\
\text { assumed that IAEA will take over surveillance and inventory validation at this time (FY } \\
\text { 1996). }\end{array}$ \\
\hline $\begin{array}{l}\text { PFP material will continue to be available for transfer to } \\
\text { user programs as requested and subsequently approved by } \\
\text { the Office of Nuclear Weapons Management }\end{array}$ & Agree \\
\hline $\begin{array}{l}\text { Excess Pu-238 at Hanford will either be shipped to SRS for } \\
\text { recovery or transferred to EM for disposition }\end{array}$ & Agree \\
\hline \multirow[t]{2}{*}{$\begin{array}{l}\text { Returns and withdrawals will be scheduled in accordance } \\
\text { with the schedule received from DOE-HO in June } 1994\end{array}$} & $\begin{array}{l}\text { The June } 94 \text { Returns/Withdrawals forecast only schedules returns from LLNL to Hanford; } \\
\text { no other Pu movements are forecasted for Hanford. Only material that meets Hanford } \\
\text { acceptance criteria may be scheduled for returns as storable material at Hanford. } \\
\text { Therefore, it is assumed that only } 6 \mathrm{~kg} \mathrm{Pu} \text { (FY 95) and } 4 \mathrm{~kg} \mathrm{Pu} \mathrm{(FY} \mathrm{96)} \mathrm{will} \mathrm{be} \mathrm{received} \\
\text { as stored inventory. }\end{array}$ \\
\hline & $\begin{array}{l}\text { Pu stabilization will occur for reactive scrap solids and a small amount of chloride solution } \\
\text { (as a process test). Disposition of nitrates and liquids will be determined in the PFP EIS } \\
\text { and Record of Decision. }\end{array}$ \\
\hline
\end{tabular}




\section{Plutonium Requirements}

\section{Defense Programs}

\section{$\leq 7 \%$ Pu-240 Product Shipments}

All $<7 \%$ Pu-240 plutonium product in stable form (does not include nitrate) has been shipped off-site. There are no plans to produce any weapon grade plutonium metal. No requirements for weapon grade plutonium oxide or metal from the Hanford Site were identified in the DOE-HO assumptions for the RL MMP.

\section{Fuel Grade Product Shipments}

No Defense Programs requirements for fuel grade (FG) plutonium from the Hanford Site were identified in the DOE-HQ assumptions for the RL MMP.

\section{Research \& Development Programs}

In accordance with the returns and withdrawals schedule received from DOE-HO in June 1994, no withdrawals are projected throughout the MMP reporting period for Nuclear Energy programs (NE) or any other programs.

\section{FFTF Driver Fuel and LMFBR Test Fuel}

Due to the FFTF shutdown directive, dated December 15, 1993, no SNM requirements are'projected for NE Hanford programs.

\section{Certified Ceramic Grade Plutonium Oxide Inventory}

A total of $357 \mathrm{~kg} \mathrm{Pu}$ (not decayed) of 16-16.75\% Pu-240 ceramic grade oxide, prepared by Los Alamos National Laboratory (LANL) during FY 1982-1983 for the Breeder Program, is in storage at WHC. No requirements for this material are currently forecasted. The oxide is held in an excess but usable " $M$ " account (project M-GE-0221-OCX, Ceramic Grade Pu Oxide-RL). 


\section{Restricted Use Plutonium Allocations}

Plutonium restricted to non-explosive use is assumed to be available to NE programs upon DP supply authorization. The current identity of the allocated* material is as follows:

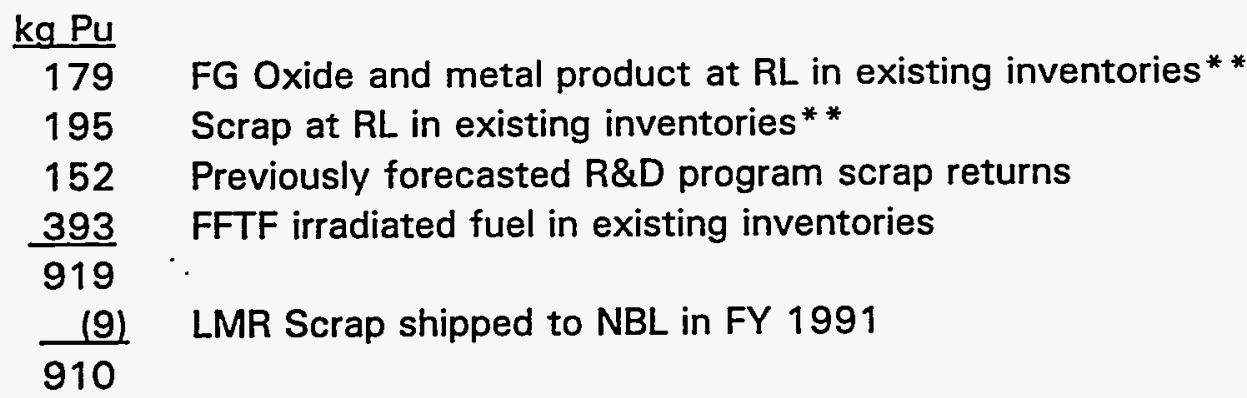

Disposition or recovery of the restricted use plutonium contained in Hanford DP existing inventories is dependent upon the PFP NEPA review.

At this time there are no processing plans to recover restricted use plutonium contained in projected Liquid Metal Reactor (LMR) scrap returns (mainly Pu-U) or FFTF irradiated fuel which remains in the NE inventory (no returns projected).

* Reference: Memorandum dated April 14, 1989, Revised Draft Allocation of Non-weapon Grade Plutonium, from Materials Planning Division (DP-131) to $R L, C H, A L$, and $S R$. (SRD) [RL document control number RL-HQ-405]

* * The original allocations per the above reference were $199 \mathrm{~kg} \mathrm{Pu}$ of product and $175 \mathrm{~kg} \mathrm{Pu}$ of scrap. In the RL MMP the quantities have been adjusted to reflect that $20 \mathrm{~kg} \mathrm{Pu}$ of scrap, previously forecasted as recovered to product form, will remain in scrap form indefinitely. 
Table 1A. N Reactor Irradiated Fuel in K Basins

$\mathrm{kg} \mathrm{Pu}$

All Cases

Fiscal Year Ending Inventory

$\frac{1994}{4028} \quad \frac{1995}{4025} \quad \frac{1996}{4022} \quad \frac{1997}{4019} \quad \frac{1998}{4017} \quad \frac{1999}{4014} \quad \frac{2000}{4012} \quad \frac{2001}{4010} \quad \frac{2002}{4008} \quad \frac{2003}{4006} \quad \frac{2004}{4004} \quad \frac{2005}{4002}$

Table 1B. Isotopics of Stored N Reactor Irradiated Fuels

(At fiscal year end)

\section{All Cases}

\begin{tabular}{|c|c|c|c|c|c|c|c|c|c|}
\hline FY & Grade & MTU & $\mathrm{kg} \mathrm{U-235}$ & $\mathrm{kg} P u$ & $\%$ U-235 & $\%$ Pu-239 & $\% \mathrm{Pu}-240$ & $\%$ Pu-241 & $\underline{\mathrm{kg} \mathrm{Np}}$ \\
\hline \multirow[t]{3}{*}{1994} & $<7 \%$ & 332 & 2966 & 223 & 0.890 & 94.49 & 5.12 & 0.389 & 2.51 \\
\hline & FG & 1764 & 13166 & $\underline{3805}$ & $\underline{0.750}$ & 84.93 & 13.44 & 1.630 & 57.21 \\
\hline & & 2096 & 16132 & 4028 & 0.772 & 85.46 & 12.98 & 1.561 & 59.72 \\
\hline \multirow[t]{3}{*}{2005} & $<7 \%$ & 332 & 2966 & 222 & 0.890 & 94.65 & 5.13 & 0.229 & 2.51 \\
\hline & FG & 1764 & 13166 & 3778 & $\underline{0.750}$ & $\underline{85.50}$ & 13.53 & $\underline{0.966}$ & $\underline{57.21}$ \\
\hline & & 2096 & 16132 & 4000 & 0.772 & 86.01 & 13.06 & 0.925 & 59.72 \\
\hline
\end{tabular}

Notes: 1. Plutonium quantities reflect decay of Pu-241.

2. The percent Pu-240 includes Pu-238 and Pu-242.

3. Total basin plutonium as of March 31,1994 in project $\mathrm{H}-\mathrm{EW}-3135-\mathrm{OBP}$ is $4029 \mathrm{Kg}$. 


\section{Table 2. DP Unirradiated Plutonium Summary} for WHC Programs and M Projects

by

NMMSS Project and Material Category

(as of March 31, 1994)

$\mathrm{kg} \mathrm{Pu}$

\begin{tabular}{|c|c|c|c|c|c|c|c|c|c|}
\hline \multirow[b]{2}{*}{ Project } & \multirow[b]{2}{*}{ Scrap } & \multirow{2}{*}{$\begin{array}{c}\text { Taiwan Rx } \\
\text { Substitution } \\
\text { Scrap }\end{array}$} & \multirow{2}{*}{$\begin{array}{c}\text { Standards } \\
\& \\
\text { Samples }\end{array}$} & \multirow{2}{*}{$\begin{array}{l}\text { Holdup } \\
\& \ln \\
\text { Process }\end{array}$} & \multirow{2}{*}{$\begin{array}{l}\text { Lab. } \\
\text { Matl. }\end{array}$} & \multicolumn{3}{|c|}{ Product } & \multirow[b]{2}{*}{ Total } \\
\hline & & & & & & Oxide & Nitrate & Metal & \\
\hline H-GE-0221-000 & 0.4 & & 1.9 & 4.6 & 22.2 & & & & 29.1 \\
\hline H-GE-0221-01Z & & & & 12.7 & & & & & 12.7 \\
\hline H-GE-0221-03C & & & & 5.8 & & & & & 5.8 \\
\hline H-GE-0221-04R & & & & 51.6 & & & & & 51.6 \\
\hline H-GE-0221-06N & & & & & & & 234.8 & & 234.8 \\
\hline H-GE-0221-06S & 1357.4 & 88.1 & & 0.7 & & & & & $1,446.2$ \\
\hline H-GE-0221-06X & & & & & & 351.2 & & & 351.2 \\
\hline H-GE-0221-OSP & & & & 13.4 & & & & & 13.4 \\
\hline H-GE-0221-OZM & & & & 1.3 & & & & & 1.3 \\
\hline H-GE-0347-030 & & & 0.2 & 1.0 & & & & & 1.2 \\
\hline H-GE-0348-060 & 0.1 & & & & & & & & 0.1 \\
\hline M-GE-0221-00X & & & 15.0 & & & 183.5 & & & 198.5 \\
\hline M-GE-0221-OCX & & & & & & 356.5 & & & 356.5 \\
\hline M-GE-0221-03M & & & & & & & & 732.0 & 732.0 \\
\hline Total & $1,357.9$ & 88.1 & 17.1 & 91.1 & 22.2 & 891.2 & 234.8 & 732.0 & $3,434.4$ \\
\hline
\end{tabular}

Notes:

1. Above values are not decayed

2. Does not include $10.9 \mathrm{~kg} \mathrm{Pu}$ of metal and archive samples in Hanford project H-GE-0221-03C located at LANL.

3. Does not include: Table 1A plutonium from $N$ Reactor Irradiated Fuel (EM project H-EW-3135-OBPl; other EM irradiated material; nor SNM in NE projects.

4. Does not include $0.8 \mathrm{~kg}$ Pu of waste material stored in waste drums at PFP designated for burial.

5. With the exception of $13.4 \mathrm{~kg} \mathrm{Pu}$ of PUREX holdup (H-GE-0221-0SP), all unirradiated plutonium stored in WHC facilities is located at the PFP. 


\section{Table 3. Plutonium Product Inventory}

\begin{tabular}{|c|c|c|c|c|}
\hline \multirow[b]{2}{*}{$\%$ Pu-240 } & \multicolumn{2}{|c|}{$\begin{array}{c}\text { FY } 1994 \text { Year End } \\
\text { kg Pu }\end{array}$} & \multirow[b]{2}{*}{$\begin{array}{c}\text { Total } \\
\text { Metal \& Oxide } \\
\end{array}$} & \multirow[b]{2}{*}{ Nitrate } \\
\hline & Metal & Oxide & & \\
\hline$<7 \%$ & -- & -- & -- & $208^{a}$ \\
\hline $7-10$ & -- & 1 & 1 & \\
\hline $10-13$ & 1 & $106^{b}$ & 107 & 27 \\
\hline $13-16$ & 1 & 97 & 98 & \\
\hline $16-19$ & 713 & $512^{c}$ & $1225^{b}$ & \\
\hline Total FG & 715 & 716 & 1431 & 27 \\
\hline PRG & 1 & 139 & 140 & - \\
\hline Total all grades & 716 & 855 & 1571 & 235 \\
\hline
\end{tabular}

Notes: 1. Plutonium values decayed through March 1994 result in a $16 \mathrm{~kg}$ Pu metal loss and a $12 \mathrm{~kg}$ Pu oxide loss not reflected in NMMSS project totals.

2. The product inventory contains americium buildup; removal prior to future use (if identified) may be required.

a. Consists of PUREX N Reactor nitrate $(196 \mathrm{~kg} \mathrm{Pu})$ plus PRF Nitrate $(12 \mathrm{~kg} \mathrm{Pu})$.

b. Oxide total reflects shipment of $23.6 \mathrm{~kg}$ Pu to LANL in July 1994 .

c. Includes $357 \mathrm{~kg} \mathrm{Pu}$ (not decayed) of certified ceramic grade oxide previously prepared for the LMR Program and held on M-GE-0221-OCX. 
Table 4. Unirradiated Plutonium Scrap Inventory

in WHC Programs

(1994 Fiscal Year Ending)

$\mathrm{kg} \mathrm{Pu}$

DP Scrap (H-GE-0221-06S) Stored at PFP

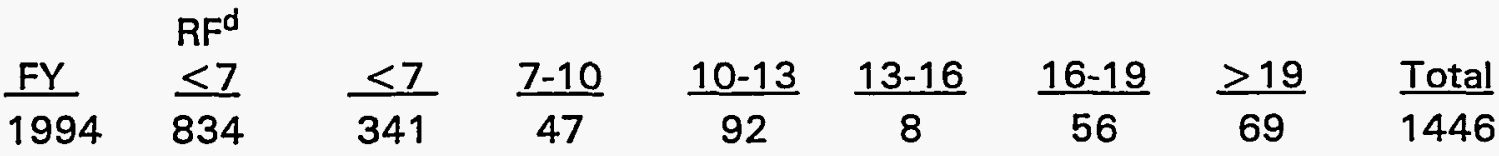

Nuclear Energy (NE) Program Unirradiated Scrap ${ }^{c, e}$

H-AF-8010 Stored at PFP

$\frac{F Y}{1994} \quad \frac{7-10}{1} \quad \frac{10-13}{192} \quad \frac{13-16}{3} \quad \frac{16-19}{6} \quad \frac{\text { PRG }}{15} \quad \frac{\text { Total }}{217}$

Nuclear Energy (NE) Program LMR Fuel Pins ${ }^{c, e}$

H-AF-8010 Stored at PFP (A) and FFTF (B)

$\begin{array}{ccccccc}\text { FY } & \frac{7-10}{0} & \frac{10-13}{384} & \frac{13-16}{0} & \frac{16-19}{0} & \frac{\text { PRG }}{12} & \frac{\text { Total }}{396} \\ \text { (A) } 1994 & 0 & 289 & 0 & 0 & 0 & 289 \\ \text { (B) } 1994 & 0 & 289 & & 0 & & \end{array}$

a. Scrap stabilization scheduled to occur in FY $1995(22 \mathrm{~kg} \mathrm{Pu})$ will not affect inventory values; scrap removals from inventory for stabilization will return to inventory as oxide scrap in FY 1995.

b. Inventories include the following: $39 \mathrm{~kg}$ Pu inventory in sources, samples, and standards in vaults and laboratories, and $91 \mathrm{~kg} \mathrm{Pu}$ in-process material and hold-up material in lines, tanks, and hoods.

c. No changes in scrap inventories are projected beyond dates shown.

d. Rocky Flats $<7 \%$ Pu-240 material includes $10 \mathrm{~kg}$ anode heels and $88 \mathrm{~kg}$ Pu of material substituted for restricted use Taiwan Research Reactor fuel.

e. These inventories consist of LMR program (H-AF-8010) scrap fuel pins and/or driver fuel assemblies. The LMR Program (NE) continues to be programmatically responsible for this material. No shipments to SRS for Central Scrap Management Office (CSMO) recovery are forecasted.

Note: Not included in this table are approximately $47 \mathrm{~kg}$ Pu in scrap material located at PFP but belonging to Hanford's Pacific Northwest Laboratory (PNL), Argonne National Laboratory (ANL)-West, and Los Alamos National Laboratory (LANL). 
Table 5. PFP Stabilization Summary

FY 1995

\begin{tabular}{||l|r|r|l||}
\hline Material for Stabilization & \multicolumn{1}{|c|}{ Items } & \multicolumn{1}{c|}{$\mathrm{kg} \mathrm{Pu}$} & Comments \\
\hline \hline Reactive Scrap Solids & & & \\
\hline$<7 \%$ Pu-240 & 203 & 20.2 & Heat Treating \\
\cline { 2 - 5 } & 30 & 0.1 & Cementing \\
\hline $8-12 \%$ Pu-240 & 33 & 0.8 & Heat Treating \\
\hline Total Solids & $266^{\mathrm{a}}$ & 21.1 & \\
\hline Scrap Chloride Solution & & & \\
\hline$<7 \%$ Pu-240 & $27^{\mathrm{b}}$ & 1.3 & Laboratory Process \\
\hline Grand Total & 293 & 22.4 & \\
\hline \hline
\end{tabular}

a. Solid items consist of either plutonium oxide (including RMC floor sweep material), plutonium oxalate, or sludges and is scheduled for processing through the muffle furnaces in HC-21C glovebox.

b. High chloride solutions stored in 10-L containers are to be transloaded to the PFP Pu Process Support Laboratory for process testing designed to demonstrate a process for converting this type solution to a stable, storable, solid. Resulting data will provide input to the PFP EIS. 


\section{Table 6. Forecast of Fuel-Grade and Power-Reactor-Grade Plutonium Unirradiated Returns}

Fiscal Year - kg Pu

Project

L-GB-0103-010
L-GE-0231-010
L-GE-0231-010
Wt. \% Pu-240

$7.0-99.0$

$7.0-19.0$

$19.0-99.0$
1995 1996-2005 $\quad$ ANSI Code

$\begin{array}{ccc}15 & 0 & \mathrm{CO} 1 \\ 27 & 0 & \mathrm{CO} 1 \\ 9 & 0 & \mathrm{CO} 1\end{array}$

Note:

No returns were forecasted from Hanford NE programs due in part to the lack of requirements for plutonium in Defense programs.

Returns schedule is based on the May 24, 1994 Withdrawal and Returns Summary received from DP-22 in June 1994.

As stated in DOE-RL's amended assumptions, only material receipts that meet Hanford's acceptance criteria are acceptable; therefore, only $10 \mathrm{~kg} \mathrm{Pu} \mathrm{(7-19 \%} \mathrm{Pu-240)} \mathrm{of} \mathrm{the} \mathrm{above}$ forecasted material is projected as SNM inventory receipts at Hanford in the FY 95 MMP.

\section{Table 7. Forecast of Fuel-Grade and Power-Reactor-Grade Plutonium Withdrawals}

In accordance with the schedule received in June 1994 from DP-22, no withdrawals from WHC projects were scheduled throughout the MMP reporting period. 


\section{Table 8. Material Usage Schedules - Plutonium}

NE Inventories in WHC Programs

as of March 31, $1994-\mathrm{kg} \mathrm{Pu}$

\begin{tabular}{|c|c|c|c|c|c|c|c|}
\hline \multirow[b]{2}{*}{ Project } & \multirow[b]{2}{*}{ Location } & \multicolumn{3}{|c|}{ Unirradiated } & \multirow[b]{2}{*}{$\begin{array}{l}\text { Unirrad. } \\
\text { Total }\end{array}$} & \multirow[b]{2}{*}{$\begin{array}{l}\text { Irrad } \\
\text { Fuelc }\end{array}$} & \multirow[b]{2}{*}{$\begin{array}{c}\text { Project } \\
\text { Total }\end{array}$} \\
\hline & & $\underline{\mathrm{PuO}}_{2}$ & MOX & $\begin{array}{l}\text { MOX } \\
\text { Fuel }\end{array}$ & & & \\
\hline $\begin{array}{l}\text { H-AF-8010-OFFa } \\
\text { FFTF Fuel }\end{array}$ & $\begin{array}{l}\text { WHC } \\
\text { PNL } \\
\text { ANL. } \\
\text { Total }\end{array}$ & $\begin{array}{l}0.4 \\
0.1 \\
0.5\end{array}$ & 11.7 & $\begin{array}{r}644.7 \\
0.2 \\
644.9\end{array}$ & $\begin{array}{r}656.8 \\
0.3 \\
657.1\end{array}$ & $\begin{array}{r}2253.9 \\
0.8 \\
4.8 \\
2259.5\end{array}$ & $\begin{array}{r}2910.7 \\
1.1 \\
4.8 \\
2916.6\end{array}$ \\
\hline $\begin{array}{l}\text { H-AF-8010-00L } \\
\text { LMFBR Test } \\
\text { Fuel }\end{array}$ & $\begin{array}{l}\text { WHC } \\
\text { PNL } \\
\text { ANL } \\
\text { LANL } \\
\text { Total }\end{array}$ & $\frac{2.9}{4.2}$ & $\begin{array}{r}201.1 \\
0.9 \\
0.6 \\
202.6\end{array}$ & $\begin{array}{r}18.9 \\
0.0 \\
5.8 \\
24.7\end{array}$ & $\begin{array}{r}221.3 \\
0.0 \\
6.7 \\
3.5 \\
231.5\end{array}$ & $\begin{array}{r}179.1 \\
1.0 \\
27.6 \\
207.7\end{array}$ & $\begin{array}{r}400.4 \\
1.0 \\
34.3 \\
3.5 \\
439.2\end{array}$ \\
\hline
\end{tabular}

H-AF-8010-OFR ANL

Fast Rctr Safety Dev

H-AF-8010-0UK WHC

Fast Rotr Safety

Dev - UK Return
5.2
5.2
0.3
5.5

$23.4 \quad 23.4$

23.4
Total
4.7
214.3
698.2

\section{$917.2 \quad 2467.5 \quad 3384.7$}

a. Due to the FFTF shutdown directive, no Plutonium requirements are projected for NE FFTF programs. Note that $393 \mathrm{~kg}$ Pu of irradiated fuel (see table 12) is designated as restricted use plutonium.

b. Unirradiated scrap with about $75 \mathrm{~kg} \mathrm{Pu}$ as $\mathrm{MOX}$ and $4 \mathrm{~kg} \mathrm{Pu}$ as $\mathrm{PuO}_{2}$ has been declared/re-declared to the Central Scrap Management Office (CSMO) during the years 1978-1985 with no disposition resulting. In accordance with MMP assumptions, unirradiated plutonium material will continue to be stored at Hanford throughout the forecast period awaiting the PFP EIS and Record of Decision (ROD) targeted for completion in CY 1996. Total does not include approximately $0.2 \mathrm{~kg} \mathrm{Pu}$ at Babcock \& Wilcox, Leechburg (YKH) and $0.6 \mathrm{~kg}$ Pu at Cimmaron Corporation (YEC).

c. FFTF spent fuel will continue to be stored indefinitely at the Hanford Site by the Office of Nuclear Energy (NE) awaiting a final decision on disposition.

Note: This table does not include NE material located at WHC facilities but belonging to PNL and other off-site projects. 


\section{Explanatory Notes for Plutonium Utilization Tables}

Separate tables are provided for $<7 \%$ Pu-240 grade, fuel grade (FG), and power reactor grade (PRG) plutonium material balances. The superscript numbers in the tables refer to the correspondingly numbered notes listed on pages preceding each table.

In the FY 1994 column, only the projected ending inventories as of September 30, 1994, are shown. The ending inventory for each year is the beginning inventory for the following year.

The letter in parentheses after the material identity shows the activity to which the material is removed or from which it is received and corresponds to the following project numbers.

Code Letter $\leq 7 \%$ FG PRG

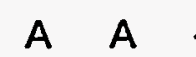

- - A

B $\quad$ B -

C C -

D D -

- H.

G I E

E $E \quad B$
NMMSS

Project No.

H-EW-3135-OBP H-AF-8010-OOL H-AF-8010-OFF

H-EW-3135-01S H-EW-3135-00A H-AF-8010-00L H-AF-8010-OFF

H-GE-0221-0SP

H-GE-0221-03C H-GE-0347-030

H-GE-0221-04R

H-GE-0221-OZM

H-GE-0221-03C

H-GE-0221-01Z

H-GE-0221-06S

H-AF-8010-

H-GE-0221-06N

H-GE-0221-06X

M-GE-0221-00X

M-GE-0221-03M

M-GE-0221-OCX

H-GE-0221-000

M-GE-0221-00X

H-GE-0347-030
Title

N Reactor Irradiated Fuel in Basin - Pu \& Np/EM LMFBR Test Fuel

FFTF Fuel

High Exposure Irradiated Fuel - Stored - RL/EM

PWR Cores - PNR

LMFBR Test Fuel

FFTF Fuel

Reactor Products Separation - Pu

Pu Conversion in Process

Process Development

Pu Reclamation - Dissolver/Solvent Extraction

Z Plant Misc. Processes

Pu Conversion in Process

Z Plant Services

Pu Scrap Inventory

LMR Program projects (Nuclear Energy/NE)

Pu Nitrate Awaiting Conversion

Pu Product - Oxide

Inactive Pu Product - Oxide - RL

Inactive Pu Product - Metal - RL

Ceramic Grade Pu Oxide

Sample Analysis

Inactive Pu Product Oxide

Process Development

Note: Code letter $A$ above refers to plutonium contained in irradiated fuels. All other code letters (B through I) refer to plutonium contained in unirradiated material.

In accordance with MMP assumptions, beginning in FY 1996 ownership of all plutonium in defense programs and $M$ accounts will transfer to $E M$; transfer of material to new EM project numbers will occur at or before this time. 
Table 9 - < 7\% Pu-240 Grade Plutonium Utilization/Inventory Projection

Explanations for Table 9 Footnote References

1. See page 21, "Explanatory Notes for Plutonium Utilization Tables," for $<7 \%$ code letters for NMMSS project numbers.

2. The planned stabilization of PFP reactive materials requires operation of muffle furnaces in glove box $\mathrm{HC}-21 \mathrm{C}$. Included in the campaign are $20 \mathrm{~kg} \mathrm{Pu}$ of reactive materials from the PFP scrap inventory; also included is $1 \mathrm{~kg} \mathrm{Pu}$ of chloride solutions from the scrap inventory as a process test.

3. In addition to the material being stabilized, the PFP scrap inventory of $<7 \%$ Pu-240 material consists mainly of stabilized scrap oxide, ash, slag and crucible, and small quantities of other scrap material (including some chloride solutions) from various sources.

4. The inventory of RF origin scrap remaining from RF shipments to the Hanford Site during FY 1984-1986 is shown separately and is not included elsewhere in Table 9. Completion of processing in PFP was delayed by plant shutdowns. Due to changes in Defense Programs plans, PFP recovery of the remaining inventory is no longer planned.

5. The plutonium was substituted for the restricted use (non-weapon use) plutonium contained in Taiwan Research Reactor (TRR) fuel processed at SRS. The RF scrap was the only material with the required Pu-240 assay, that was available in sufficient quantity and suitable form for the substitution. 
Table 9. $<7 \%$ Pu-240 Grade Plutonium Utilization/Inventory Projection ${ }^{1}$

kg Pu - Fiscal Year Ending

Base Case

A Irradiated Fuel

Ending Inventory: K Basins(N-Rx Fuel)

FFTF

Fiscal Year

$1994 \underline{1995} \underline{1996} \underline{1997} \underline{1998 *}^{*}$

$\begin{array}{lllll}223 & 223 & 223 & 223 & 223\end{array}$

$\begin{array}{lllll}11 & 11 & 11 & 11 & 11\end{array}$

B PUREX

Removal to Tank Farm Waste

Ending Inventory: PUREX in process/holdup

(solution in D5/E6 tanks)

C PFP Stabilization ${ }^{2}$

Glovebox HC-21C

Receipts: Reactive Scrap (E)

Process Dev. Lab. Test

Receipts: Chloride Solution (E)

Total

$\begin{array}{lllll} & 9 & 0 & 0 & 0 \\ 9 & 0 & 0 & 0 & 0\end{array}$

Removals: Scrap oxide (E)

Removals: Loss (1\%)

Total

Ending Inventory

0

200000

$\begin{array}{lll}0 & 0 & 0\end{array}$

$\begin{array}{llll}1 & 0 & 0 & 0\end{array}$

21000

$\begin{array}{llll}21 & 0 & 0 & 0\end{array}$

00000

$\begin{array}{llll}21 & 0 & 0 & 0\end{array}$

PFP In-Process/Holdup

Ending Inventory: PRF

RMC

PFP Building Holdup

$\begin{array}{rrrrr}51 & 51 & 51 & 51 & 51 \\ 6 & 6 & 6 & 6 & 6 \\ 4 & 4 & 4 & 4 & 4\end{array}$

Ending Inventory Total

61

61

61

61

61

E PFP Scrap Inventory

Receipts: Oxide (C)

$\begin{array}{rrrrr} & 21 & 0 & 0 & 0 \\ & 20 & 0 & 0 & 0 \\ & 1 & 0 & 0 & 0 \\ 341 & 341 & 341 & 341 & 341\end{array}$

Ending Inventory: PFP scrap 3

F Product Inventory

Ending Inventory: Product nitrate

$\begin{array}{lllll}208 & 208 & 208 & 208 & 208\end{array}$ 


\section{Table 9. $<7 \%$ Pu-240 Grade Plutonium Utilization (Continued)}

kg Pu - Fiscal Year Ending

\section{Fiscal Year \\ $1994 \underline{1995} \underline{1996} \underline{1997} \underline{1998 *}^{*}$}

G Samples and Standards

Ending Inventory: In Vaults \& Labs

Total

Lab in-process/holdup

$\begin{array}{rrrrr}11 & 11 & 11 & 11 & 11 \\ 5 & 5 & 5 & 5 & 5 \\ 16 & 16 & 16 & 16 & 16\end{array}$

\section{$<7 \%$ Pu-240 Inventory}

Irradiated Fuel: $K$ Basins $(A)$

FFTF (A)

PUREX Tank Holdup (B)

PFP Stabilization In-process (C)

PFP in-process/Holdup (D)

PFP Scrap Inventory (E)

Product Inventory (F)

Samples and Standards (G)

Subtotal

$\begin{array}{rrrrr}223 & 223 & 223 & 223 & 223 \\ 11 & 11 & 11 & 11 & 11 \\ 9 & 0 & 0 & 0 & 0 \\ 0 & 0 & 0 & 0 & 0 \\ 61 & 61 & 61 & 61 & 61 \\ 341 & 341 & 341 & 341 & 341 \\ 208 & 208 & 208 & 208 & 208 \\ 16 & 16 & 16 & 16 & 16 \\ 869 & 869 & 869 & 869 & 869\end{array}$

Scrap from Rocky Flats $<7 \%$ Pu-240 Inventory 4

Oxide $(85 \%)$

Oxide - TRR substitute 5

$\begin{array}{rrrrr}736 & 736 & 736 & 736 & 736 \\ 47 & 47 & 47 & 47 & 47 \\ 37 & 37 & 37 & 37 & 37 \\ 4 & 4 & 4 & 4 & 4 \\ 10 & 10 & 10 & 10 & 10\end{array}$

Ash/stabilized - TRR substitute 5

Ash/unstabilized - TRR substitute ${ }^{5}$

Anode heel

$\begin{array}{lllll}834 & 834 & 834 & 834 & 834\end{array}$

Subtotal

$\begin{array}{lllll}1703 & 1703 & 1703 & 1703 & 1703\end{array}$

Total Pu Inventory (<7\% Pu-240)

in WHC Programs at WHC Facilities

* In the Base Case, the FY 1998 ending inventories continue without change through the MMP period ending FY 2005. 


\section{Explanations for Table 10 Footnote References}

1. See page 21, "Explanatory Notes for Plutonium Utilization Tables," for FG code letters for NMMSS project numbers.

2. The FY 1994 Basin ending irradiated inventory does not reflect measured values from the KE Basin fuel segregation program. Instead, the FY 1995 MMP inventory values are derived from the official Safeguards PRE data base used for NMMSS reporting. The plutonium quantities and weighted average $\mathrm{Pu}-240$ percentages are based on decayed values.

3. In order to reduce security, safeguards and storage costs, a program was initiated in FY 1988 to move Nuclear Energy (NE) program scrap, fuel pins, and assemblies out of Hanford 300 area NE facilities and into the PFP for storage; this program was completed in FY 1992.

With the exception of plant hold-up and thirty two driver fuel assemblies containing $289 \mathrm{~kg}$ Pu in mixed oxide (located at the FFTF), all unirradiated plutonium material stored by WHC is located at the PFP. The NE unirradiated fuel pins currently located at the FFTF will be moved to the PFP once storage space is made available.

Table 4 includes a summary of the amount of NE plutonium that is contained in materials stored at PFP. These materials will continue to be held on NE NMMSS project numbers awaiting DOE-HO decisions as to responsibility for management and/or disposition. An additional note appears on Table 6 which does not project any NE returns during the MMP reporting period. Movement of the NE materials to PFP for storage is not a "return" in the context of DOE Order 5660.1B, Management of Nuclear Materials.

4. Projected receipts from LLNL are designated as fuel grade material only; no other receipts from off-site locations are projected in this document.

5. Table 3 shows the PFP FY 1994 ending product inventory breakdown by form and Pu-240 assay range. This inventory reflects approximately $16 \mathrm{~kg} \mathrm{Pu}$ metal decay and $12 \mathrm{~kg}$ Pu oxide decay; NMMSS report project totals do not deduct this decay loss.

6. The $16 \%$ Pu-240 certified ceramic grade plutonium oxide was originally prepared by LANL for the LMR Program. The forecasts used for the MMP do not show any program requirements for the oxide.

7. Table 12 summarizes restricted use plutonium allocations for FG and PRG material. 
Table 10. Fuel Grade Plutonium Utilization/Inventory Projection ${ }^{1}$

A Irradiated Fuel

Removals: Decay N-Rx Fuel

End Inventory: $K$ Basins ${ }^{2}$

Removals: Decay FFTF Fuel

Ending Inventory: FFTF

Restricted Use (FFTF)

Unrestricted Use (FFTF)

B PUREX

Removal to waste

Ending inventory in process

10-13

10-13

4

$10-13$

10-13

$10-13$

$10-13$

Total

Ending Inventory in process

D PFP In-Process/Holdup

Ending Inventory: PRF

PFP Building Holdup

10-13

$10-13$

End Inventory: Total in process/holdup 10-13

C PFP Stabilization

Glovebox H-21C

Receipts: Reactive Scrap (E)

$10-13$

0

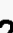

2
9

11
Fiscal Year

$19951996 \underline{1997} \underline{1998 *}^{*}$

$\begin{array}{llll}1 & 1 & 1 & 0 \\ 2 & 2 & 2 & 2\end{array}$

56
903
2779
64
3802

$\begin{array}{rrr}56 & 56 & 56 \\ 902 & 901 & 901 \\ 2777 & 2775 & 2773 \\ 64 & 64 & 64 \\ 3799 & 3796 & 3794\end{array}$

1

\section{1}

1

$\begin{array}{crrrrr}7-10 & 8 & 8 & 8 & 8 & 8 \\ 10-13 & 753 & 752 & 752 & 752 & 751 \\ 13-16 & 199 & 199 & 199 & 199 & 199 \\ >16 & 1220 & 1219 & 1219 & 1219 & 1218 \\ \text { Total } & 2180 & 2178 & 2178 & 2178 & 2176\end{array}$

$\begin{array}{llllll}>16 & 270 & 270 & 270 & 270 & 270\end{array}$

$\begin{array}{rrrrrr}7-10 & 8 & 8 & 8 & 8 & 8\end{array}$

$\begin{array}{llllll}10-13 & 753 & 752 & 752 & 752 & 751\end{array}$

$\begin{array}{llllll}13-16 & 199 & 199 & 199 & 199 & 199\end{array}$

$\begin{array}{llllll}>16 & 950 & 949 & 949 & 949 & 948\end{array}$

$\begin{array}{llllll}\text { Total } & 1910 & 1908 & 1908 & 1908 & 1906\end{array}$

$\begin{array}{llll}4 & 0 & 0 & 0 \\ 0 & 0 & 0 & 0\end{array}$

1

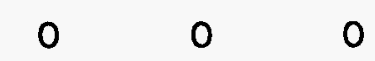

1

1
0
1

$\begin{array}{lll}0 & 0 & 0 \\ 0 & 0 & 0 \\ 0 & 0 & 0\end{array}$

0

0

00

2
9

2

22

11

11

11

11 
Table 10. Fuel Grade Plutonium Utilization (Continued)

kg Pu - Fiscal Year Ending

Fiscal Year

\%Pu-240 1994 1995 1996 1997 1998*

E PFP Scrap Inventory

Receipts: Oxide (C)

Removals: Reactive Scrap (D)

10-13

$10-13$

End Inv: PFP Scrap

$\begin{array}{crrrrr}7-10 & 47 & 47 & 47 & 47 & 47 \\ 10-13 & 92 & 92 & 92 & 92 & 92 \\ 13-16 & 8 & 8 & 8 & 8 & 8 \\ >16 & 56 & 56 & 56 & 56 & 56 \\ & & & & & \\ \text { Total } & 203 & 203 & 203 & 203 & 203\end{array}$

Restricted Use

$\begin{array}{crrrrr}7-10 & 35 & 35 & 35 & 35 & 35 \\ 10-13 & 71 & 71 & 71 & 71 & 71 \\ 13-16 & 6 & 6 & 6 & 6 & 6 \\ >16 & 51 & 51 & 51 & 51 & 51 \\ & & & & & \\ \text { Total } & 163 & 163 & 163 & 163 & 163\end{array}$

Unrestricted Use

$\begin{array}{crrrrr}7-10 & 12 & 12 & 12 & 12 & 12 \\ 10-13 & 21 & 21 & 21 & 21 & 21 \\ 13-16 & 2 & 2 & 2 & 2 & 2 \\ >16 & 5 & 5 & 5 & 5 & 5 \\ & & & & & \\ \text { Total } & 40 & 40 & 40 & 40 & 40\end{array}$

F NE Program Material ${ }^{3}$

Fuel Pins at the FFTF

10-13

289

40

40

40

Fuel Pins at the PFP

$10-13$

384

$\begin{array}{llll}289 & 289 & 289 & 289\end{array}$

$\begin{array}{llllll}\text { Total } & 673 & 673 & 673 & 673 & 673\end{array}$

Ending Inventory: NE Fuel Pins

$384 \quad 384 \quad 384$

Ending Inventory: NE Scrap Storage

$\begin{array}{crrrrr}7-10 & 1 & 1 & 1 & 1 & 1 \\ 10-13 & 192 & 192 & 192 & 192 & 192 \\ 13-16 & 3 & 3 & 3 & 3 & 3 \\ >16 & 6 & 6 & 6 & 6 & 6\end{array}$

Restricted Use

$\begin{array}{llllll}\text { Total } & 202 & 202 & 202 & 202 & 202 \\ 10-13 & 137 & 137 & 137 & 137 & 137\end{array}$

Unrestricted Use

$7-10$

10-13

$13-16$

$>16$

1

1
55
3
6
65

1
55
3
6
65

1
55
3
6
65

$\begin{array}{rr}1 & 1 \\ 55 & 55 \\ 3 & 3 \\ 6 & 6 \\ 65 & 65\end{array}$


Table 10. Fuel Grade Plutonium Utilization (Continued)

kg Pu - Fiscal Year Ending

Fiscal Year

\%Pu-240 $1994 \underline{1995} \underline{1996} \underline{1997} 1998 *$

G Product Inventory

Receipts: LLNL Oxide ${ }^{4}$ (table 6)

13-16

6

400

Ending Inv: Nitrate

$10-13$

27

27

27

27

27

End Inv: Oxide and Metals

$\begin{array}{crrrrr}7-10 & 1 & 1 & 1 & 1 & 1 \\ 10-13 & 107 & 107 & 107 & 107 & 107 \\ 13-16 & 98 & 104 & 108 & 108 & 108 \\ >16 & 868 & 868 & 868 & 868 & 868 \\ & & & & & \\ \text { Total } & 1074 & 1080 & 1084 & 1084 & 1084\end{array}$

Total Product Inventory 5

$\begin{array}{crrrrr}7-10 & 1 & 1 & 1 & 1 & 1 \\ 10-13 & 134 & 134 & 134 & 134 & 134 \\ 13-16 & 98 & 104 & 108 & 108 & 108 \\ >16 & 868 & 868 & 868 & 868 & 868 \\ & & & & & \\ \text { Total } & 1101 & 1107 & 1111 & 1111 & 1111 \\ & & & & & \\ >16 & 179 & 179 & 179 & 179 & 179 \\ >16 & 0 & 0 & 0 & 0 & 0 \\ 7-10 & 1 & 1 & 1 & 1 & 1 \\ 10-13 & 134 & 134 & 134 & 134 & 134 \\ 13-16 & 98 & 104 & 108 & 108 & 108 \\ >16 & 689 & 689 & 689 & 689 & 689 \\ & & & & & \\ \text { Total } & 922 & 928 & 932 & 932 & 932\end{array}$

H Ceramic Grade Oxide ${ }^{6}$

Ending Inventory

$\begin{array}{llllll}>16 & 357 & 357 & 357 & 357 & 357\end{array}$

I Samples and Standards

Ending Inventory: In Vaults/Labs

$\begin{array}{crrrrr}7-10 & 6 & 6 & 6 & 6 & 6 \\ 10-13 & 19 & 19 & 19 & 19 & 19 \\ 13-16 & 1 & 1 & 1 & 1 & 1 \\ >16 & 1 & 1 & 1 & 1 & 1 \\ \text { Total } & 27 & 27 & 27 & 27 & 27\end{array}$

Lab in-process/holdup

7-10

$\begin{array}{rr}1 & 1 \\ 28 & 28\end{array}$

1
28

1
28

1
28

Total Ending Inventory

28

28 
Table 10. Fuel Grade Plutonium Utilization (Continued)

kg Pu - Fiscal Year Ending

Fiscal Year

\%Pu-240 $1994 \quad \underline{1995} \underline{1996} \underline{1997}$ 1998* $^{*}$

Total Fuel Grade Plutonium Inventory Inventory

Basins Irradiated (A)

FFTF Irradiated (A)

PUREX Holdup (B)

PFP Stabilization (C)

PFP In-Process/Holdup (D)

PFP Scrap (E)

LMR Scrap (F)

LMR Fuel Pins (F)

Product (G)

Ceramic Grade Oxide (H)

Samples and Standards (I)

Total

$\begin{array}{rrrrr}3805 & 3802 & 3799 & 3796 & 3794 \\ 2180 & 2178 & 2178 & 2178 & 2176 \\ 4 & 0 & 0 & 0 & 0 \\ 0 & 0 & 0 & 0 & 0 \\ 11 & 11 & 11 & 11 & 11 \\ 203 & 203 & 203 & 203 & 203 \\ 202 & 202 & 202 & 202 & 202 \\ 673 & 673 & 673 & 673 & 673 \\ 1101 & 1107 & 1111 & 1111 & 1111 \\ 357 & 357 & 357 & 357 & 357 \\ 28 & 28 & 28 & 28 & 28 \\ 8564 & 8561 & 8562 & 8559 & 8555 \\ & & & & \\ & & & & \\ 3805 & 3802 & 3799 & 3796 & 3794 \\ 1910 & 1908 & 1908 & 1908 & 1906 \\ 4 & 0 & 0 & 0 & 0 \\ 0 & 0 & 0 & 0 & 0 \\ 11 & 11 & 11 & 11 & 11 \\ 40 & 40 & 40 & 40 & 40 \\ 65 & 65 & 65 & 65 & 65 \\ 673 & 673 & 673 & 673 & 673 \\ 922 & 928 & 932 & 932 & 932 \\ 357 & 357 & 357 & 357 & 357 \\ 28 & 28 & 28 & 28 & 28 \\ 7815 & 7812 & 7813 & 7810 & 7806\end{array}$

Unrestricted Use

Basins Irradiated (A)

FFTF Irradiated (A)

PUREX Holdup (B)

PFP Stabilization (C)

PFP In-Process/Holdup (D)

PFP Scrap (E)

LMR Scrap (F)

LMR Fuel Pins (F)

Product (G)

Ceramic Grade Oxide (H)

Samples and Standards (I)

Subtotal

Restricted Use 7

Basins Irradiated (A)

FFTF Irradiated (A)

PUREX Holdup (B)

PFP Stabilization (C)

PFP In-Process/Holdup (D)

PFP Scrap (E)

LMR Scrap (F)

LMR Fuel Pins (F)

Product (G)

Ceramic Grade Oxide (H)

Samples and Standards (I)

Subtotal

270

270

270

270

270

Total

$\begin{array}{rrrrr}163 & 163 & 163 & 163 & 163 \\ 137 & 137 & 137 & 137 & 137 \\ 179 & 179 & 179 & 179 & 179 \\ & & & & \\ 749 & 749 & 749 & 749 & 749 \\ & & & & \\ 8564 & 8561 & 8562 & 8559 & 8555\end{array}$


Table 10. Fuel Grade Plutonium Utilization (Continued)

kg Pu - Fiscal Year Ending

\%Pu-240 $1994 \quad \underline{1995} \underline{1996} \underline{1997} \underline{1998 *}^{*}$

Total Fuel Grade Plutonium Inventory by $\mathrm{Pu}-240$ percent

$\begin{array}{lrrrrrr} & 7-10 & 120 & 120 & 120 & 120 & 120 \\ \text { Inventory } & 10-13 & 2782 & 2776 & 2775 & 2774 & 2773 \\ & 13-16 & 3090 & 3094 & 3096 & 3094 & 3092 \\ & >16 & 2572 & 2571 & 2571 & 2571 & 2570 \\ \text { Unrestricted Use } & \text { Total } & 8564 & 8561 & 8562 & 8559 & 8555 \\ & 7-10 & 85 & 85 & 85 & 85 & 85 \\ & 10-13 & 2574 & 2568 & 2567 & 2566 & 2565 \\ & 13-16 & 3084 & 3088 & 3090 & 3088 & 3086 \\ & >16 & 2072 & 2071 & 2071 & 2071 & 2070 \\ \text { Restricted Use } & & & & & & \\ & \text { Subtotal } & 7815 & 7812 & 7813 & 7810 & 7806 \\ & 7-10 & 35 & 35 & 35 & 35 & 35 \\ & 10-13 & 208 & 208 & 208 & 208 & 208 \\ & 13-16 & 6 & 6 & 6 & 6 & 6 \\ & >16 & 500 & 500 & 500 & 500 & 500 \\ & & & & & & \\ & \text { Subtotal } & 749 & 749 & 749 & 749 & 749 \\ & & & & & & \\ & \text { Total } & 8564 & 8561 & 8562 & 8559 & 8555\end{array}$

* FY 1998 inventories continue without change through the MMP period ending FY 2005. 
Table 11 - Power Reactor Grade (PRG) Plutonium Utilization

\section{Explanations for Table 11 Footnote References}

1. See page 21, "Explanatory Notes for Plutonium Utilization Tables," for PRG code letters for NMMSS project numbers.

2. In the Base Case, the FY 1998 ending inventories continue without change through the MMP period ending FY 2005.

3. FFTF PRG irradiated fuel inventory declines FY 1996 (by $1 \mathrm{~kg} \mathrm{Pu}$ ) due to decay.

4. No PFP stabilization operations are scheduled for PRG material.

5. PRG plutonium scrap will continue to be stored at the Hanford site.

6. See note 3 on page 25 .

7. Table 12 summarizes restricted use plutonium allocations for FG and PRG material. 
Table 11. Power Reactor Grade Plutonium Utilization/Inventory Projection ${ }^{1,2}$ kg Pu - Fiscal Year Ending

A Irradiated Fuel at Hanford End Inv: PWR Core 2 Blanket End Inv: High Exposure K Reactor End Inv: FFTF ${ }^{3}$

Unrestricted Use

Restricted Use (FFTF)

\begin{tabular}{|c|c|c|c|c|c|}
\hline \multirow[b]{2}{*}{$\% \mathrm{Pu}-240$} & \multicolumn{5}{|c|}{ Fiscal Year } \\
\hline & 1994 & 1995 & 1996 & 1997 & 1998 \\
\hline $26-30$ & 120 & 120 & 120 & 120 & 120 \\
\hline 26 & 9 & 9 & 9 & 9 & 9 \\
\hline $20-23$ & 242 & 242 & 241 & 241 & 241 \\
\hline Total & 371 & 371 & 370 & 370 & 370 \\
\hline $26-30$ & 248 & 248 & 247 & 247 & 247 \\
\hline $20-23$ & 123 & 123 & 123 & 123 & 123 \\
\hline
\end{tabular}

B PFP Scrap Inventory

End Inventory: Storage ${ }^{4,5}$

23

69

69

69

69

69

Restricted Use

23

32

32

32

32

32

Unrestricted Use

37

37

37

37

C LMR Program Scrap 6

Ending Inventory Scrap

Ending Inventory LMR Fuel Pins

$\begin{array}{cccccc}20-24 & 15 & 15 & 15 & 15 & 15 \\ 22 & 12 & 12 & 12 & 12 & 12\end{array}$

Restricted Use

20-24

22

15

15

15

15

15

Unrestricted Use

$\begin{array}{crrrrr}19-43 & 139 & 139 & 139 & 139 & 139 \\ 44 & 1 & 1 & 1 & 1 & 1\end{array}$

Unrestricted Use

$19-44 \quad 140$

140

$140 \quad 140 \quad 140$

E Samples and Standards

21

1

1

1

1

1

Total Power Reactor Grade Plutonium Inventory Unrestricted Use Irradiated Fuel-PWR, K-Rx,FFTF (A)

PFP Scrap (B)

LMR Fuel Pins (C)

Product Inventory (D)

Samples and Standards (E) Subtotal

$\begin{array}{rrrrr}248 & 248 & 247 & 247 & 247 \\ 37 & 37 & 37 & 37 & 37 \\ 12 & 12 & 12 & 12 & 12 \\ 140 & 140 & 140 & 140 & 140 \\ 1 \frac{1}{438} & 438 & 437 & 437 & 437\end{array}$

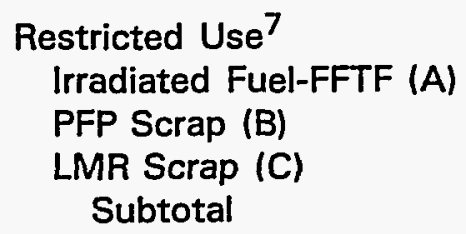

$\begin{array}{lllll}123 & 123 & 123 & 123 & 123\end{array}$

$\begin{array}{lllll}32 & 32 & 32 & 32 & 32\end{array}$

$\frac{15}{170} \quad \frac{15}{170} \quad \frac{15}{170} \quad \frac{15}{170} \quad \frac{15}{170}$

Total

$\begin{array}{lllll}608 & 608 & 607 & 607 & 607\end{array}$ 
WHC-SP-1139

Table 12. RL Inventory Allocation of Restricted Use Plutonium

$\mathrm{kg} \mathrm{Pu}$

Restricted Use Account

UK Barter:

FFTF \& Test Fuel ${ }^{a}$

NFS/Licensed Facility:

Product Inventory (G)

Scrap Inventory (E,B)

LMR Program Scrap $(F, C)$

NFS Totals ${ }^{b}$

Shipped for $\mathrm{NBL}^{\mathrm{C}}$

Unused Allocation

Total RL Restricted Use
FG

PRG

Total

270

123

393

\begin{tabular}{lcc}
179 & -- & 179 \\
163 & $32^{\mathrm{d}}$ & 195 \\
$137^{\mathrm{e}}$ & $\frac{15^{\mathrm{e}}}{47}$ & $\underline{152}$ \\
479 & 526 \\
$\frac{(6)}{473}$ & $\underline{(3)}$ & $\underline{(9)}$ \\
$\underline{44}$ & $\underline{517}$ \\
\hline
\end{tabular}

743

167

Notes: 1. Capital letters in parentheses indicate project account in Plutonium Utilization Tables 10 and 11.

2. Allocations are based on the DOE-HQ/DP-131 memorandum dated April 14 1989, "Revised Draft Allocation of Non-weapon-grade Plutonium", to Operations Offices. (RL document control number RL-HQ-405)

3. Does not include material substituted for the Taiwan Research Reactor restricted use fuel processed at the SRS (see table 9).

a. Restricted use allocation is assigned to NE irradiated inventory. Original plutonium before irradiation was mainly $12 \% \mathrm{Pu}-240$.

b. See Table 13 for NFS-West Valley nitrate shipments received at RL.

c. Supplied in FY 1991 for New Brunswick Laboratory (NBL) standards.

d. $20 \mathrm{~kg}$ of restricted use Critical Mass Laboratory (CML) nitrate identified as PRG product in 1991 MMP will remain as scrap nitrate.

e. Based on the inventory of LMR Program scrap stored at PFP (Table 4): 
Table 13. RL Receipts of NFS Plutonium Nitrate

\begin{tabular}{|c|c|c|c|c|c|}
\hline Transfer $\mathrm{N}$ & Vo. & Month/Year & Pu Origin/Reactor & Pu-240 Wt\% & kg Pu Elemer \\
\hline DAA-HWA & $1-5$ & N/A & N Reactor & N/A & $N / A$ \\
\hline $\begin{array}{l}\text { DAA-HWA } \\
\text { DAA-HWA } \\
\text { DAA-HWA } \\
\text { DAA-HWA } \\
\text { DAA-HWA }\end{array}$ & $\begin{array}{l}6 \\
7 \\
8 \\
9 \\
10\end{array}$ & $\begin{array}{l}7 / 67 \\
7 / 67 \\
7 / 67 \\
8 / 67 \\
9 / 67\end{array}$ & $\begin{array}{l}\text { Dresden } \\
\text { Yankee } \\
\text { Yankee } \\
\text { Yankee } \\
\text { Yankee }\end{array}$ & $\begin{array}{l}\text { No Data } \\
15 \text { est. }^{\mathrm{a}} \\
15 \text { est. }^{\mathrm{a}} \\
13.2 \text { non-fiss. } \\
14.5 \text { non-fiss. }\end{array}$ & $\begin{array}{r}1.869 \\
36.925 \\
52.937 \\
77.145 \\
27.864\end{array}$ \\
\hline $\begin{array}{l}\text { DAA-HVA } \\
\text { DAA-HVA } \\
\text { DAA-HVA }\end{array}$ & $\begin{array}{l}1 \\
2 \\
3-33\end{array}$ & $\begin{array}{c}10 / 67 \\
10 / 67 \\
\text { N/A }\end{array}$ & $\begin{array}{l}\text { Yankee } \\
\text { Yankee } \\
\text { N Reactor }\end{array}$ & $\begin{array}{l}14.9 \text { non-fiss. } \\
16.1 \text { non-fiss. } \\
\text { N/A }\end{array}$ & $\begin{array}{r}64.390 \\
20.148 \\
\text { N/A }\end{array}$ \\
\hline DAX-HVA & $1-2$ & N/A & SEFOR & N/A & N/A \\
\hline $\begin{array}{l}\text { YDE-HVA } \\
\text { YDE-HVA } \\
\text { YDE-HVA } \\
\text { YDE-HVA } \\
\text { YDE-HVA }\end{array}$ & $\begin{array}{l}1 \\
2 \\
3 \\
4 \\
5\end{array}$ & $\begin{array}{r}9 / 70 \\
9 / 70 \\
9 / 70 \\
10 / 70 \\
10 / 70\end{array}$ & $\begin{array}{l}\text { Yankee } \\
\text { Commonw. Edison } \\
\text { Consolid. Edison } \\
\text { Yankee } \\
\text { Commonw. Edison }\end{array}$ & $\begin{array}{l}14.795 \\
23.349 \\
15.630 \\
15.014 \\
22.584\end{array}$ & $\begin{array}{l}34.359 \\
29.795 \\
23.232 \\
34.138 \\
18.795\end{array}$ \\
\hline $\begin{array}{l}\text { YDE-HVA } \\
\text { YDE-HVA } \\
\text { YDE-HVA } \\
\text { YDE-HVA }\end{array}$ & $\begin{array}{l}6 \\
7 \\
8 \\
9\end{array}$ & $\begin{array}{l}10 / 70 \\
10 / 70 \\
10 / 70 \\
10 / 70\end{array}$ & $\begin{array}{l}\text { Consolid. Edison } \\
\text { No. States Power } \\
\text { Yankee } \\
\text { Commonw. Edison }\end{array}$ & $\begin{array}{r}16.009 \\
7.921 \\
14.902 \\
23.456\end{array}$ & $\begin{array}{r}37.474 \\
7.036 \\
37.775 \\
22.844\end{array}$ \\
\hline $\begin{array}{l}\text { YDE-HVA } \\
\text { YDE-HVA } \\
\text { YDE-HVA } \\
\text { YDE-HVA } \\
\text { YDE-HVA } \\
\text { YDE-HVA } \\
\text { YDE-HVA }\end{array}$ & $\begin{array}{l}10 \\
11 \\
12 \\
13 \\
14 \\
15 \\
16\end{array}$ & $\begin{array}{l}10 / 70 \\
12 / 70 \\
12 / 70 \\
12 / 70 \\
12 / 70 \\
12 / 70 \\
3 / 73\end{array}$ & $\begin{array}{l}\text { Consolid. Edison } \\
\text { Yankee } \\
\text { Commonw. Edison } \\
\text { Consolid. Edison } \\
\text { Consumers Power } \\
\text { Consumers Power } \\
\text { Consumers Power }\end{array}$ & $\begin{array}{l}16.850 \\
14.505,15.652 \\
23.300 \\
16.975 \\
13.233,15.390 \\
13.844 \\
21.264-7 \text { bot. } \\
19.512-1 \text { bot. }\end{array}$ & $\begin{array}{l}21.050 \\
38.625 \\
20.391 \\
22.210 \\
42.117 \\
21.315 \\
12.093\end{array}$ \\
\hline YMU-HVA & 1 & $5 / 73$ & Vermont Yankee ${ }^{b}$ & 9.18 & 9.075 \\
\hline DAA-HVA & $34-46$ & N/A & N Reactor Fuel Retn. & N/A & N/A \\
\hline
\end{tabular}

$\begin{array}{rlllll}\text { By Pu-240 Wt\%: } & \frac{8-9}{\text { kg Pu: }} \quad 16.111 & \frac{13-15}{469.459} & \frac{15-17}{124.114} & \frac{\text { FG Total }}{609.684} & \frac{\text { PRG Total }}{103.918}\end{array}$

a. Based on Yankee Pu-240 assays listed below.

b. Involved trade between Vermont Yankee and Commonwealth Edison. 


\section{Table 14. Total Plutonium Inventory \\ MMP Beginning Inventory \\ $\mathrm{kg} \mathrm{Pu}$}

\begin{tabular}{|c|c|c|c|c|c|}
\hline \multirow[b]{3}{*}{ Inventory Type } & ects, M Accoun & ts, \& EM Proje & cts (irradiated fo & & \\
\hline & \multicolumn{4}{|c|}{ At WHC Hanford Facilities } & \multirow{2}{*}{$\frac{\text { Offsite }}{\text { Total }}$} \\
\hline & Table $9<7 \%$ & Table $10 \mathrm{FG}$ & Table 11 PRG & Total & \\
\hline Irradiated (EM) & 223 & 3805 & 129 & 4157 & \\
\hline In-process/Holdup (DP) & 70 & 15 & 0 & 85 & \\
\hline $\begin{array}{l}\text { Scrap (DP) } \\
\text { Scrap from Rocky Flats (DP) }\end{array}$ & $\begin{array}{l}341 \\
834\end{array}$ & $\begin{array}{r}203 \\
0\end{array}$ & $\begin{array}{r}69 \\
0\end{array}$ & $\begin{array}{l}613 \\
834\end{array}$ & \\
\hline $\begin{array}{l}\text { Product: Nitrate (DP) } \\
\text { Metal \& Oxide (DP \& M) } \\
\text { Ceramic Grade Oxide (M) }\end{array}$ & $\begin{array}{r}208 \\
0 \\
0\end{array}$ & $\begin{array}{r}27 \\
1074 \\
357\end{array}$ & $\begin{array}{r}0 \\
140 \\
0\end{array}$ & $\begin{array}{r}235 \\
1214 \\
357\end{array}$ & \\
\hline Standards \& Samples (DP) & 11 & 27 & 1 & 39 & 11 \\
\hline Laboratory In-process/Holdup (DP) & 5 & 1 & & 6 & \\
\hline MMP 9/30/94 Projected Inventory & 1692 & 5509 & 339 & 7540 & \\
\hline \multicolumn{6}{|l|}{ Add: } \\
\hline \multicolumn{6}{|l|}{ Material not in tables } \\
\hline Product Oxide to LANL, 7/94 (DP) & & +24 & & +24 & \\
\hline Irradiated Fuel Decay, 4/1-9/30/94 (EM) & & +1 & & +1 & \\
\hline Prod Decay in tables/not in NMMSS DP,M & & +28 & & +28 & \\
\hline MMP Beginning Inventory (3/31/94) & 1692 & 5562 & 339 & 7593 & 11 \\
\hline
\end{tabular}

\begin{tabular}{|c|c|c|c|c|c|}
\hline \multicolumn{6}{|c|}{ WHC Programs: NE Projects } \\
\hline \multirow[b]{2}{*}{ Inventory Type } & \multicolumn{4}{|c|}{ At WHC Hanford Facilities } & \multirow{2}{*}{$\frac{\text { Offsite }}{\text { Total }}$} \\
\hline & Table 9 & Table $10 \mathrm{FG}$ & Table 11 PRG & Total & \\
\hline Irradiated (NE) & 11 & 2180 & 242 & 2433 & 35 \\
\hline Unirradiated Fuel Pins \& Assemblies (NE) & & 673 & 12 & 685 & 0 \\
\hline Scrap (NE) & & 202 & 15 & 217 & 16 \\
\hline MMP Beginning Inventory (3/31/94) & 11 & 3055 & 269 & 3335 & 51 \\
\hline
\end{tabular}

Total MMP Beginning Inventory (3/31/94) in WHC Programs, and M Accounts

\begin{tabular}{|r|r|}
\hline At WHC & Offsite \\
\hline 10928 & 62 \\
\hline
\end{tabular}

Note: 1. This table does not include $67 \mathrm{~kg}$ Pu of offsite program material located at WHC facilities (PNL $45 \mathrm{~kg}$ Pu, LANL $17 \mathrm{~kg} \mathrm{Pu,} \mathrm{and} \mathrm{ANL} 5 \mathrm{~kg}$ Pu).

2. No $E$ accounts remain in WHC facilities; all former $E$ account material was transferred into to EM projects. 
Appendix A - Uranium Usage Tables 
Table A-1. Fuel Fabrication Unirradiated Uranium Inventory (DP)

Inventory as of March 31, 1994

H-GE-0112-OOF

COEI MTU \% U-235 $\underline{\mathrm{kg} \mathrm{U}-235}$

Enriched Uranium

$\begin{array}{lrrrr}\text { Billets } & 254 & 626^{\mathrm{a}} & 0.95 & 5947 \\ & 254 & 234 & 1.25 & 2920 \\ \text { Finished Fuel } & 257 & 622^{\mathrm{b}} & 0.95 & 5915 \\ & 257 & 134^{\mathrm{c}} & 1.15 & 1538 \\ & & & & \\ \text { Unfinished Fuel } & 256 & 113 & 0.95 & 1077 \\ & 256 & \underline{15} & 1.25 & 183 \\ \text { Total } & & 1744 & & 17580\end{array}$

Natural Uranium

$\begin{array}{lrrr}\text { Billets } & 254 & 80 & 0.71 \\ \text { Finished Fuel } & 257 & 66 & 0.71 \\ \text { Unfinished Fuel } & 256 & -9 & 0.71 \\ \text { Total } & & 155 & \\ & & & \\ \text { Total Inventory } & & 1899^{\mathrm{d}} & \end{array}$

a. Reflects shipment of 326 MTU to the United Kingdom in 1st quarter FY 1993.

b. Inventory does not include 2 MTU $(21 \mathrm{~kg} \mathrm{U}-235)$ of unirradiated contaminated finished fuel elements contained in Hanford's K-East irradiated fuel storage basin.

c. "Spike" finished fuel elements $(1.15 \% \mathrm{U}-235)$ consist of $0.95 \%$ U-235 inner fuel pieces combined with $1.25 \%$ U-235 outer fuel pieces.

d. Does not include approximately $0.5 \mathrm{MTU}(4 \mathrm{~kg} \mathrm{U}-235)$ of scrap metal or $34 \mathrm{~kg} \mathrm{U}(0.3 \mathrm{~kg}$ $\mathrm{U}-235$ ) in unirradiated scrap solutions. 
Table A-2. DP/EM Enriched \& Normal Uranium Inventory and Usage MTU - Fiscal Year Ending

Irradiated Fuel in Basins

EM Ending Inventory: K-Basins ${ }^{1}$

$1994 \quad 1995 \quad 1996 \quad 1997 \quad 1998-2005$

$\begin{array}{lllll}1421 & 1421 & 1421 & 1421 & 1421\end{array}$

Unirradiated U (Fuel Fab)

Removals: Transfer to $\mathrm{EM}^{2}$

1901

000

DP Ending Inventory ${ }^{3}$.

EM Ending Inventory

$\begin{array}{rrrrr}1901 & 0 & 0 & 0 & 0 \\ 0 & 1901 & 1901 & 1901 & 1901\end{array}$

\section{PUREX/PFP Facilities}

Removals: Transfer to tank farm waste 4 Transfer PUREX acid waste to BNFL Transfer to EM

160

0

0

7

DP Ending Inventory: PUREX In process 16 PUREX Acid Waste 7

0

0

0 o
PFP Scrap 5

$0 \quad 0$

$0 \quad 0$

0

$\begin{array}{ll}0 & 0 \\ 0 & 0\end{array}$

EM Ending Inventory: PFP Scrap

0

0

1

1

1

$\mathrm{UO}_{3}$ Plant

Removals: Transfer to $\mathrm{EM}^{2}$

622

662

DP Ending Inventory: $\mathrm{UO}_{3}$ Product $^{6}$

EM Ending Inventory: $\mathrm{UO}_{3}$ Product

$\begin{array}{rrrrr}62 & 0 & 0 & 0 & 0 \\ 0 & 662 & 662 & 662 & 662\end{array}$

Ending Inventory

DP total

EM total

Total

$\begin{array}{rrrrr}2587 & 1 & 0 & 0 & 0 \\ 1421 & 3984 & 3985 & 3985 & 3985 \\ 4008 & 3985 & 3985 & 3985 & 3985\end{array}$

1. 675 MTU of N-Reactor counterpart irradiated fuel in K-basins is DU and therefore not reported. Other EM owned irradiated fuel (PWR Core II and Single pass reactor fuel) contains virtually no EU or NU and were also not reported on this table.

2. Assumes EM is willing to accept material transfers in FY 1995.

3. Includes 2 MTU of unirradiated contaminated finished fuel elements in KE Basin.

4. EM tank farm waste is not carried as SNM stored inventory.

5. EU and NU counterpart of Pu/U scrap stored at PFP.

6. $0.85 \%$ U-235

Note: Does not include $103 \mathrm{MTU}$ of depleted $\mathrm{UO}_{3}$ in storage remaining after shipment of approximately 3 MTU to Oak Ridge Y-12 plant in June 1993. 
Table A-3. NE Unirradiated Uranium

in WHC programs as of March 31, 1994 (all weights in kilograms)

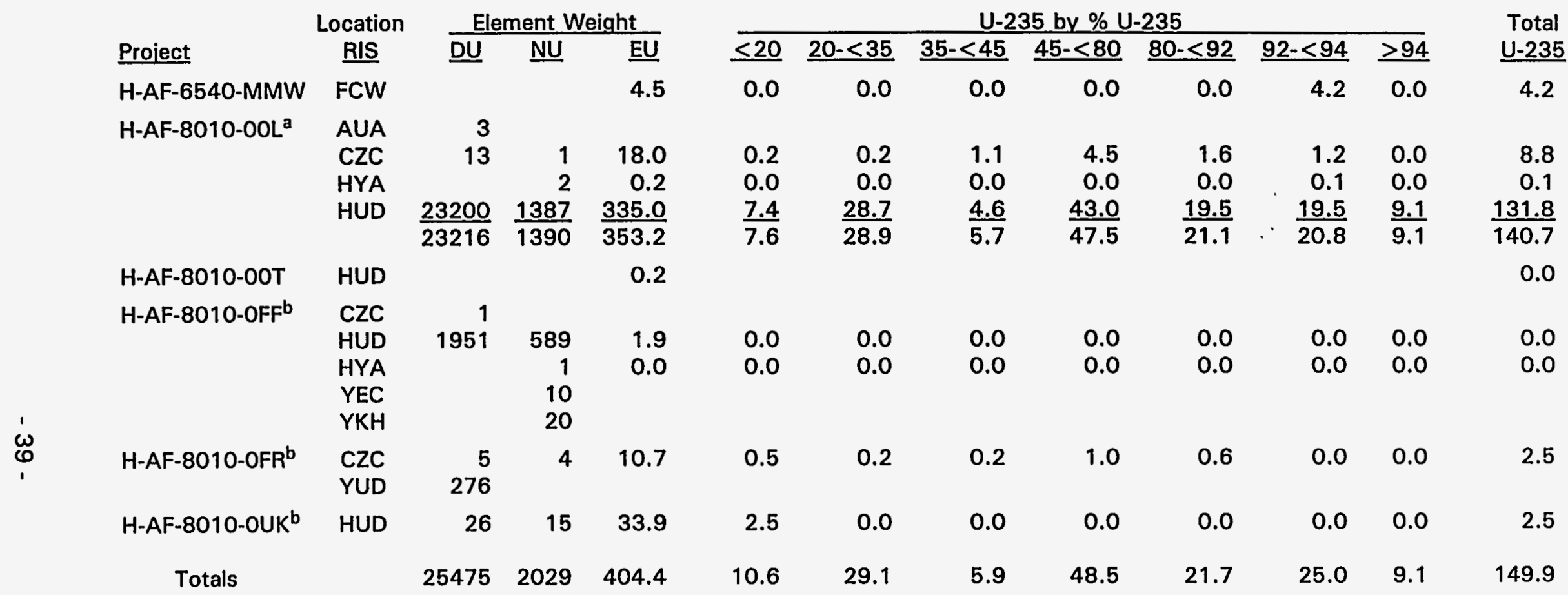

a Due to the FFTF shutdown directive, no future uranium requirement usage are projected for Hanford NE Programs.

b Storage at WHC will continue indefinitely until a decision on final disposition is reached.

Definition of location RIS codes: FCW Babcock and Wilcox

AUA Los Alamos National Laboratory

CZA Argonne National Laboratory

CZC Argonne National Laboratory - West

HYA Pacific Northwest Laboratory (PNL)

HUD Westinghouse Hanford Company (WHC)

XJZ GPU Nuclear Corp. Three Mile Island 2

YEC Cimarron Corporation

YKH Babcock and Wilcox, Plutonium Laboratory, Leechburg

YUD SNPC, Richland discard to ground and lagoon. 
Table A-4 NE Irradiated Uranium

in WHC programs as of March 31, 1994 (all weights in kilograms)

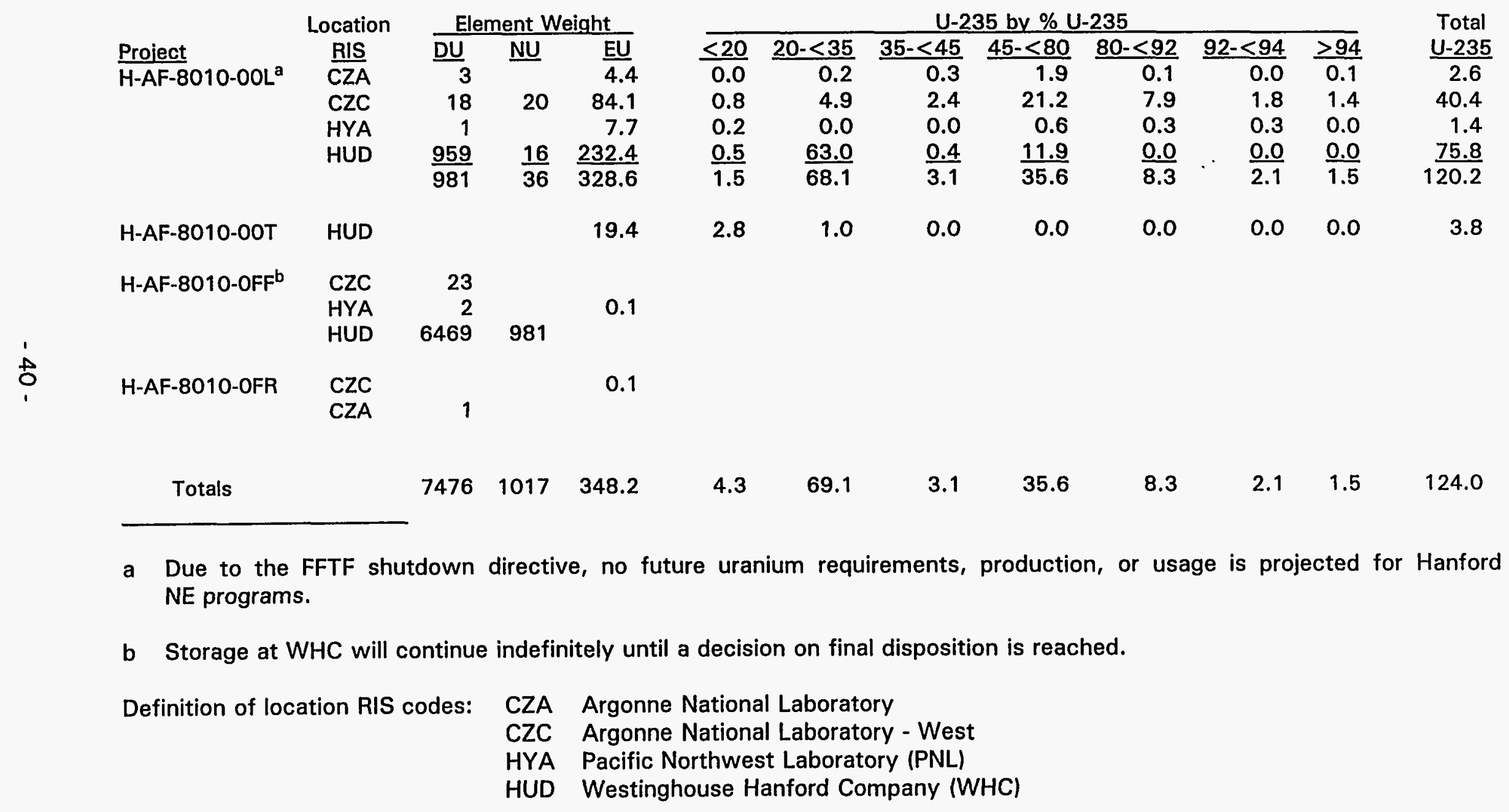




\section{Appendix B - Other Special Nuclear Materials}


Table B-1. Other SNM in WHC Programs

Pu-238 (MT 83)

\begin{tabular}{|c|c|c|c|c|c|c|}
\hline \multirow{2}{*}{$\begin{array}{c}\text { Location } \\
\text { RIS }\end{array}$} & \multirow[b]{2}{*}{ Location } & \multirow[b]{2}{*}{ Project } & \multirow[b]{2}{*}{ COEI } & \multirow[b]{2}{*}{$\%$ Pu-238 } & \multicolumn{2}{|c|}{ Grams } \\
\hline & & & & & $\mathrm{Pu}$ & Pu-238 \\
\hline AVB & Mound, EG\&G & H-AF-8010-00L & 781 & 78 & 5.9 & 4.6 \\
\hline HYA & PNL & H-GE-0347-030 & $\begin{array}{l}409 \\
746 \\
771\end{array}$ & $\begin{array}{l}85 \\
85 \\
85\end{array}$ & 2.4 & 2.1 \\
\hline \multirow[t]{4}{*}{ HUD } & \multirow[t]{4}{*}{ WHC } & H-AF-8010-00L & 781 & 80 & 24.8 & 19.5 \\
\hline & & H-GE-0221-000 & 771 & 78 & 84.7 & 67.7 \\
\hline & & H-GE-0221-000 & 781 & 80 & 3.3 & 2.1 \\
\hline & & H-GE-0347-030 & 771 & 80 & 2.1 & 1.7 \\
\hline
\end{tabular}

Heat standards and samples; material at Mound is for calibration

Tritium (MT 87)

\begin{tabular}{|l|l|l|l|l|}
\hline Location RIS & Location & Project & COEI & Grams Tritium \\
\hline \hline HUD & WHC & H-AF-8010-00L & 746 & 0.5 \\
\hline
\end{tabular}

Getter beds at FFTF resulting from Japanese MOTA experiments.

U-233 (MT 71)

\begin{tabular}{||l|l|l|l|l|l||}
\hline Location RIS & Location & Project & COEI & $\mathrm{kg} \mathrm{U}$ & $\mathrm{kg} \mathrm{U}-233$ \\
\hline \hline \multirow{4}{*}{ HUD } & & H-AF-8010-00L & 771 & 0.08 & 0.07 \\
\cline { 3 - 6 } & \multirow{4}{*}{ WHC } & H-GE-0221-000 & 771 & 0.04 & 0.04 \\
\cline { 3 - 6 } & & H-GE-0221-06S & 728 & 0.04 & 0.04 \\
\hline
\end{tabular}

Standards and Samples.

Np-237 (MT 82)

\begin{tabular}{||l|l|l|l|l||}
\hline Location RIS & Location & Project & COEI & kg Np-237 \\
\hline \multirow{2}{*}{ HUD } & \multirow{2}{*}{ WHC } & H-AF-8010-OFF & 360,375 & 2 \\
\cline { 3 - 5 } & & H-EW-3135-OBP & 376 & 60 \\
\hline
\end{tabular}

$\mathrm{Np}-237$ contained in irradiated fuel. 